\title{
INQUIRY-BASED INSTRUCTION AND TEACHER'S COMPETENCES FOR ITS REALIZATION
}

\author{
Jiř́ DOSTÁL*, Univerzita Palackého v Olomouci
}

Přijato: 16. 2. 2015 / Akceptováno: 25. 5. 2015

Typ článku: Výzkum

DOI: $10.5507 /$ jtie.2015.001

Abstract: The article deals with a research of the teachers' competences bounded to the realization of the inquiry-based instruction. It sees competences as a necessary part of the teacher's abilities and advocates this topic into the other authors' works' context. It provides an overview of the current state of the solved issue and presents the partial results of the realized researches which became the base for the realization of a broader investigation which is in the article presented. The aim of the research was to define (via appropriate approaches) which competences of a teacher are the key ones for the realization of the inquiry-based instruction, which are the basic ones and the threshold ones. This all became a base for a creation of a competence model.

Key words: inquiry-based instruction, competence, teacher, education.

\section{BADATELSKY ORIENTOVANÁ VÝUKA A KOMPETENCE UČITELE K JEJÍ REALIZACI}

Resumé: Článek se zabývá výzkumem učitelských kompetencí vázaných krealizaci badatelsky orientované výuky. Nahliži na kompetence jako na nezbytnou součást učitelské výbavy, přičemž zasazuje toto téma do kontextu praci dalšich autorů. Poskytuje přehled o aktuálním stavu řě̌ené problematiky a prezentuje dilči výsledky realizovaných výzkumných šetření, které se staly podkladem pro realizaci rozsáhlejšího výzkumu, který je v tomto článku prezentován. Výzkumné šetřeni si kladlo za cíl vhodnými postupy určit, které kompetence učitele jsou pro realizaci badatelsky orientované výuky klićové, základní a prahové, což se stalo podkladem pro tvorbu kompetenčního modelu.

Klíčová slova: badatelsky orientovaná výuka, kompetence, učitel, vzdělávání. 


\section{1 Úvod}

Vzdělávání prochází od svého počátku změnami vyvolanými různými př́icinami. Jedním z významných hybných faktorů jsou požadavky kladené na jedince v souvislosti $\mathrm{s}$ jeho začleněním do společnosti, životem $\mathrm{v}$ ní a jejím perspektivním rozvojem. $\mathrm{V}$ průběhu historického vývoje se požadavky a potřeby mění stejně tak, jako společenské hodnoty, a proto je možné se v určitých obdobích setkat s důrazem na tělesný rozvoj, umělecký rozvoj, na rozvoj manuálních dovedností, vnímání, myšlení, na osvojení si poznatků, nebo na uplatnitelnost nabytého poznání v běžném životě. Aktuální společenské potřeby kladou důraz na výchovu člověka s tvůrčím myšlením, schopného problémy nejen nacházet, ale je i účinně řešit, kooperativního, aktivního, soutěživého, avšak současně tolerantního a chránícího slabší. Už na prvním stupni základní školy by mělo vzdělávání svým činnostním a praktickým charakterem a uplatněním odpovídajících metod motivovat žáky $\mathrm{k}$ dalšímu učení, vést je $\mathrm{k}$ učební aktivitě a k poznání, že je možné hledat, objevovat, tvořit a nalézat vhodnou cestu $\mathrm{k}$ řešení problémů.

S ohledem na požadavky společnosti a její představy o ideálně vzdělaném jedinci jsou hledány cesty, jak tohoto stavu dosáhnout. Jsou voleny vhodné obsahy vzdělávání, organizační formy, výukové metody, podnětná vzdělávací prostředí, využívána moderní didaktická technika, vytvářeno pozitivní klima, hledány nové cesty v př́pravě učitelů atp. Pokud tyto segmenty nasměrujeme tak, aby odpovídaly výše uvedeným aktuálním společenským potřebám, tj. aby přispívaly $\mathrm{k}$ jejich uspokojování $\mathrm{v}$ oblasti výchovy a vzdělávání člověka, dospíváme $\mathrm{k}$ jednomu $\mathrm{z}$ aktuálně diskutovaných pojetí výuky označovanému jako badatelsky orientovaná výuka, viz např. S. Abels (2014). Potřeba uplatňování netradičních přístupů ve výuce je vyvolána i odlišností dětí od dřívějších generací. Více nežli dř́ve do jejich života vstupují informační média a v důsledku toho disponují větším množstvím poznatků, které jsou schopny aktuálně získávat nezávisle na učiteli. $\mathrm{V}$ důsledku proměny rodinné výchovy jsou děti kritičtější a akceptace předávaných poznatků již není srovnatelná s dř́vějšími generacemi, které byly výrazně pod vlivem autority učitele. Jiné jsou i zájmy dětí, které se odklonily od tradiční techniky a přírodních věd, což se projevuje taktéž ve volbě povolání, viz studie zadaná MŠMT (Důvody nezájmu žáků o př́rodovědné a technické obory. Výzkumná zpráva, 2008).

Uvedené skutečnosti kladou nové podněty na rozvoj pedagogické teorie, především se zaměřením na učitele, který je projektantem výuky a výrazným způsobem ovlivňuje její konkrétní podobu. Kvalita učitelů a jejich kompetence se tak stávají klíčovými pro výsledné pojetí výuky i její výsledky a s nimi spojené naplnění společenských potřeb. Soubor profesního, expertního vědění učitele, je základem $\mathrm{k}$ hlubšímu porozumění a kompetentnímu řešení praktických problémů a reálných výukových situací (srov. Spilková a Wildová, 2014). Toho si již delší dobu všímají odborníci na mezinárodní úrovni a ve svých pracích zaměřují pozornost cíleně právě na tuto oblast (srov. např. Day, 2012; Klieme, Maag-Merki a Hartig, 2010).

\section{Kompetence učitele pro navozování a řízení badatelských aktivit žáků}

V souladu s autory E. Alake-Tuenter, H. J. A. Biemans, H. Tobi a kol. (2012, s. 2624) nahlížíme na učitele jako na ,architekta“ ovlivňujícího koncepci výuky, tj. jako na klíčový prvek. Požadujeme-li respektování osobnosti dítěte a má-li výuka být přizpůsobena předchozí zkušenosti žáka, je role učitele nezastupitelná a v podstatě sehrává nejvýznamnější roli. Ostatní prvky, tj. metody, organizační formy, materiální 
prostředky aj. jsou převážně dány volbou učitele a mohou mít spíše akcelerační či inhibiční charakter ve směru dosahování stanoveného záměru rozvoje osobnosti žáka. Významnou roli rovněž sehrávají kurikulární dokumenty, které vytváří rámec, ve kterém se učitel při koncipování výuky pohybuje.

Realizace badatelsky orientované výuky je pro učitele poměrně náročnou a to již ve fázi jejího projektování. Vyžaduje patřičné kompetence, což vyplývá i z prací autorů X. Fazio, W. Melville a A. Bartley (2010), I. Rikmanis, J. Logins a D. Namsone (2012) a dokumentů Science Education in Europe: National Practices, Policies and Research, (2011), Inquiry and the National Science Education Standards : a guide for teaching and learning (2000) nebo Evolution of Student Interest in Science and Technology Studies, Policy Report (2006).

$\mathrm{S}$ pozoruhodným zjištěním přišli autoři W. Melville, X. Fazio, A. Bartley a D. Jones (2008). Zjistili, že schopnost učitelů badatelsky vyučovat závisí na jejich vlastních zkušenostech $\mathrm{s}$ bádáním a jejich dovednosti přemýšlet o možnostech transferu badatelských aktivit do výuky. Oprávněně lze tedy klást otázku, jaké zkušenosti s bádáním získají studenti učitelských oborů, tj. budoucí učitelé, a zda jsou dostatečné pro pozdější uskutečňování kvalitní badatelsky orientované výuky v pedagogické praxi. A může vůbec pregraduální príprava $\mathrm{v}$ plné míre poskytnout potřebné kompetence? Požadavek na kvalitní učitelskou př́pravu vznášejí i ve své práci i R. Duncan, V. Pilitsis a M. Piegaro (2010). Požadují, aby učitelské studijní programy vybavily budoucí učitele kompetencemi nezbytnými pro kritické myšlení a vytváření a modifikaci učebních materiálů tak, aby byly orientovány více badatelsky.

Sami učitelé však zaujímají pozitivní postoj $\mathrm{k}$ realizaci badatelsky orientované výuky, což vyplývá např̀. Z mezinárodního výzkumného šetření TALIS 2013 (TALIS 2013 Results: An International Perspective on Teaching and Learning, 2014, s. 397). Zjištěné přesvědčení učitelů o potřebě realizovat výuku badatelsky je více nežli pozitivní, nicméně vyvstává rozpor mezi přesvědčením učitelů a dosaženými výsledky žáků $\mathrm{v}$ testech PISA, které jsou spíše průměrné. Výzkumně bylo potvrzeno, napřr. A. G. Thompson (1984), že přsesvědčení učitelů se nemusí vždy shodovat $s$ jejich skutečně uplatňovanými vyučovacími postupy. Vlivy mohou být různé, mj. již zmíněné nedostatečné kompetence učitelů.

Při badatelsky orientované výuce se mění role učitele, „který se stává garantem metody, ne garantem pravdy“ (srov. Tomková, 2005). Učitel se stává facilitátorem žákova učení, pomáhá mu hledat efektivní cesty $\mathrm{k}$ učení, mj. využíváním škály vyučovacích metod, aktivizujících hlavně myšlenkové procesy žáka, a kooperativních strategií výuky. Hlavními úkoly učitele ve výuce je vytváření a zadávání "dobrých" problémů, které stimulují zkoumání a dále vytváření skupinových aktivit moderujících a usnadñujících proces konstrukce znalostí (Vermeersch, 2005, s. 48). Jak uvádí R. S. Prawat (1977), učitel se při badatelsky orientované výuce musí vyhnout roli "dávkovače znalosti““ (dispenser of knowledge) nebo roli pouhého „průvodce“ (facilitator).

Problematika kompetencí učitele ve vztahu k realizaci badatelsky orientované výuky $v$ sobě z hlediska vstupů zahrnuje více oblastí. Především je zmínit pojem kompetence, jelikož tento pojem není doposud významově ustálen. Z tohoto důvodu čtenáře odkazujeme na práce R. Bader a M. Müller (2002), S. Tobon (2009), E. Jung (2005), H. Belz a M. Siegrist (2001). Kompetence učitele jsou nosným tématem pedeutologie, konkrétně se kompetencím vztaženým k profesi učitele ve svých pracích věnovali mnozí 
přední pedagogové, mj. V. Švec (1999), J. Vašutová (2007), E. Walterová (2002), D. Nezvalová (2007), B. Lazarová a kol. (2006), F. Korthagen (2004), F. E. Weinert (2001), D. Hustler a D. Intyre (1996), P. P. Grimmett a G. L. Erickson (1988), J. Calderhead (1989) nebo A. Pollard a S. Tann (1987).

Otázka profesionalizace učitelského povolání je, jak uvádí A. Vališová a H. Kasíková (2007, s. 18), teoretickým i praktickým problémem. Zmiňují (tamtéž, s. 19), že „,badatelé soustředèni na studium vývoje jednotlivých profesnich skupin zdůraznili, že jak samotné profese, tak i výchova budoucich profesionálủ jsou proménlivé. "

Profesi chápeme jako poměrně jasně vymezenou pracovní roli. Přesněji lze pojem profese vymezit jako „povoláni spojené s určitou kvalifikací nebo odbornými vlastnostmi a dovednostmi, většinou vykonávané na základě zákonného oprávněni" (Průcha, 2002, s. 19). Již v tomto vymezení je zřetelný důraz na předpoklady jedince, které ho opravňují $\mathrm{k}$ výkonu profese, a které ho současně odlišují od neprofesionálů. Akcent na předpoklady jedince je možné doložit i vymezeními dalších autorů na obecné úrovni (zejm. profesní psychologie a personální management), tak i prímo v kontextu učitelské profese:

- D. Špok (2014) uvádí: „U profese však vnímáme důraz na celkovou roli, zodpovédnosti a výsledky, které produkuje, a dovednosti, znalosti a schopnosti, které její nositel musí mít. Pokud hovořime o profesi, pak často hovořime právě o dovednostech, kvalitách či predpokladech, které pro ni musíme ziskat. Ve spojitosti s profesi tedy hovořime často o profesním vzdělávání, profesni kvalifikaci..."

- A. Vališová a H. Kasíková (2008, s. 19), uvádějí „...základní podminkou profesionalizace je ovládnutí specializovaného souboru vědomostí a dovedností, které jsou osvojeny v prủběhu prodlouženého obdobi vzděláváni a tréninku..."

Předpoklady, kterými by měl učitel disponovat, aby mohl být označen za profesionála, jsou v čase proměnlivé. Jako významný faktor se uplatňují představy a požadavky společnosti kladené na vzdělávací systém. Společnost prostřednictvím politických a jiných rozhodnutí vytvárí představu o tom, jaký člověk má být vychován, jaké hodnoty má zastávat a jakými znalostmi, dovednostmi a postoji má disponovat. Poměrně často bývá v této souvislosti zmiňován pojem kompetence. S ohledem na tuto skutečnost, ale i jiné okolnosti, dochází k proměnám vzdělávání jako celku a potažmo $\mathrm{s}$ tím i $\mathrm{k}$ proměnám požadavků kladených na učitele.

V této souvislosti se velmi často hovoří o kvalitě učitele a realizaci kvalitní výuky. $\mathrm{V}$ pedagogické teorii a vzdělávací praxi je dlouhodobě hledána odpověd' na otázku, jaký učitel musí být, aby byla výuka kvalitní? Ne vždy byla odpověd' jednoznačná, napřr. dokument Improving Teacher Quality in the United States (2014, s. 2) uvádí, že „,ti, kteři při výuce kladli větší důraz na kvantitativní aspekt, byli považováni za kvalitni učitele, nebo stejně tak byli považováni za kvalitní učitele ti, kteři získali certifikaci státního úradu. "

K označení pojmu „ideální“ učitel bývá v literatư̌e užívána celá řada blízkých, nebo významově se překrývajících termínů, mj. R. Švaříček (2006, s. 2) zmiňuje termíny kompetentní učitel, dobrý učitel, kvalitní učitel, tvořivý učitel, zkušený učitel, učitel veterán, efektivní učitel, výjimečný učitel a učitel expert. D. R. Cruickshank a D. Haefele (2001, s. 29) uvádí mj. jako variantní termíny učitel expert, kompetentní učitel, dobrý učitel, efektivní učitel, reflektivni učitel, respektovaný učitel a ideální učitel. V historii se můžeme setkat $\mathrm{s}$ celou řadou teoretických př́stupů $\mathrm{k}$ uchopení kvality učitele, které budou dále charakterizovány. Klíčovou a dodnes často diskutovanou otázkou je, jakým 
způsobem nejvhodněji vyjádřit a zachytit kvalitu učitele. Na tuto otázku neprímo ve své práci reaguje i V. Spilková (2010, s. 70) a uvádí, že ,řada odborných studii se pokusila na základě empirických výzkumů identifikovat kompetence (znalosti, dovednosti, hodnoty, osobnostní předpoklady), které charakterizuji kvalitní, efektivní učitele. Modely kvalitniho, efektivniho učitele byly vytváreny v souvislosti nebo v rámci modelì kvalitní, efektivní, dobré školy a kvalitní, dobré výuky. " Požadavky na kvalitu učitele bývají zachycovány v podobě „standardů“, které (tamtéž, s. 71) bývají nejčastěji formulovány $\mathrm{v}$ podobě klíčových profesních kompetencí jako soubor znalostí, dovedností, hodnot a postojü, nebo v podobě charakteristik klíčových profesních činností, které jsou nezbytné pro kvalitní/standardní výkon profese v dané zemi.

\section{Současný stav empirických šetření zaměřených na kompetence učitelů $k$ realizaci badatelsky orientované výuky}

Ve výzkumné práci jsme navazovali na výzkumné nálezy a závěry vyplývající z již realizovaných šetření. Oblast učitelských kompetencí v kontextu badatelsky orientované výuky je v mezinárodním měřítku řešena již řadu let, nicméně ne př́liš provázaně, spíše se jedná o separované studie. $Z$ našeho pohledu však přinášejí cenná zjištění, která se mohou v mnohém stát východisky pro další výzkumnou práci.

Mezi prvními uved'me autory P. A. Kirschner, J. Sweller a R. A. Clark (2006), kteří si všímají skutečnosti, že je velmi důležité, aby učitelé měli osvojeny patřičné kompetence. Uvádějí: „Pokud jsou učitelé přesvědčeni o tom, že badatelsky orientované vyučování je prrinosnějsín, nežli př́mé (transmisivní), potřebuji kompetence, aby mohli ř́dit proces bádání. Bez těchto kompetenci docházi ke kvalitativně nedostatečnému vedeni a zpětné vazbě v procesu bádání, které je zároveň méně efektivni.“ Ze závěrů jejich práce vyplývá, že nestačí na kvalitu výuky působit $\mathrm{z}$ vnějšku, např. prostřednictvím kurikulárních dokumentů, prostřednictvím změny přesvědčení, ale i prostřednictvím kompetenčního rozvoje. Povšimněme si však i toho, že autoři ve své práci uvažují i přesvědčení učitele, které se promítá do postojové roviny, což je velmi podstatné.

K podobnému zjištění dospívá i A. Colburn (srov. 2000, s. 42), když ve své práci upozorňuje na to, že ,jedním z di̊vodů, proč učitelé nerealizuji badatelsky orientovanou výuku je, že se cití nedostatečně připraveni, nemají osvojeny patřičné kompetence." Mezi další faktory zařazuje přesvědčení učitelů, že badatelsky orientovaná výuka se dá realizovat pouze $\mathrm{s}$ žáky $\mathrm{s}$ vysokou mírou znalostí, dále, že je obtížné badatelské aktivity žáků řídit, a zvyklost vyučovat fakta. Taktéž M. L. Martinelllo (1998) si ve své práci povšiml, že významnou překážkou v realizaci badatelsky orientované výuky jsou schopnosti a znalosti učitelů.

Rovněž výzkumy autorů O. Lee, J. E. Hart, P. Cuevas a C. Enders (2004), S. McDonald a S. B. Songer (2008) a E. H. van Zee, D. Hammer, M. Bell, P. Roy a J. Peter (2005) ukázaly, že někteří učitelé základních škol mají problém s efektivitou badatelsky orientované výuky. U problémových učitelů se projevuje nedostatek znalostí o bádání a zejména o implementaci badatelsky orientované výuky ve svých třídách.

C. Chambers $(2002$, s. 3) ve své práci upozorňuje na skutečnost, že učitel působí na žáky jako vzor. Učitel podle něho musí být kompetentní využívat badatelské metody, musí umět badatelsky myslet. Žáci ho napodobují a učí se klást otázky, na které hledají odpovědi. Podobně jako výše uvedení autoři klade důraz na kompetence učitele, když uvádí: „Bez správného pedagogického vedeni může učitel při badatelsky 
orientované výuce udělat více škody, nežli užitku. Žáci by si mohli vytvořit falešné představy o předmětu bádání, a náprava může vyžadovat mnoho času.“

Pozoruhodné výzkumné šetření v souvislosti s kompetencemi učitelů bylo realizováno v Norsku. Autoři S. A. Sikko, R. Lyngved a B. Pepin (2012, s. 15) zjistili, že norští učitelé potřebují více kurzi̊, které jim umožní rozvíjet nezbytné kompetence pro realizaci badatelsky orientované výuky. Současný stav pokládají za nedostatečný.

Z uvedeného je zřetelné, že i přesvědčení učitelů sehrává významnou roli, na což se mj. zaměřili autoři C. J. Eick a B. Stewart (2010) a C. T. Forbes a E. A. Davis (2010). Zjistili, že pokud učitelé vidí prírodní vědy jako soubor faktů, je jen malá, nebo téměř žádná pravděpodobnost, že budou rozvíjet bádání u žáků. Podobně se autoři J. Weld a L. Funk (2005) zaměřili na postoje učitelů a zjistili, že „nadšení“ (enthusiastic) učitelé měli tendenci podporovat př́rodovědné bádání častěji, nežli „negativně“ ladění učitelé.

Výzkumy dokládají, že nejen kompetence sehrávají př̀i badatelsky orientované výuce významnou roli. Lze se setkat s výzkumnými zjištěními, napřs. B. Kleve (2007), že významnou překážkou $\mathrm{v}$ realizaci badatelských učebních aktivit je čas, který je ve výuce omezený. Autoři K. Maaß a M. Euler (2011) rovněž upozorňují na problémy spojené s hodnocení výkonu žáka.

Lze oprávněně tvrdit, že realizované výzkumy dostatečně prokázaly potřebu kompetentnosti učitelů, jakožto klíčového faktoru ovlivňujícího kvalitu a podobu badatelsky orientované výuky. Otázkou je, jakými kompetencemi by tedy učitelé měli disponovat? O nalezení odpovědi na tuto otázku se pokusili autoři E. Alake-Tuenter, H. J. A. Biemans, H. Tobi a kol. (2012), když analyzovali diskutované prvky v současné literatuře. Uvedení autoři zjištují značnou neshodu. Názory na podobu nezbytných kompetencí nejsou sjednoceny, což dokládají i autoři M. Kim a A. L. Tan (2011), kteř́ uvádějí, že „odborníci jsou podobného názoru ohledně chybějicí jednoznačné shody $v$ prípadě kompetencí, které učitelé potřebuji k realizaci badatelsky orientované výuky.“ Důsledkem této neshody je neexistence verifikovaného kompetenčního modelu ve vztahu $\mathrm{k}$ badatelsky orientované výuce.

Zmiňovaní autoři E. Alake-Tuenter, H. J. A. Biemans, H. Tobi a kol. (2012), $\mathrm{s}$ vědomím problému ohledně nejednoznačnosti toho, jaké kompetence musí učitelé mít, aby mohli realizovat badatelsky orientovanou výuku, identifikovali dvacet tři dílčích kompetencí, které rozdělili do tří skupin: předmětové znalosti (vázané na obsah vzdělávání), pedagogické znalosti a postoje. I přes tuto snahu autorů obohatit pedagogickou teorii a praxi, nejsme přssvědčeni o úplnosti a plné využitelnosti vytvořeného souboru kompetencí.

Poměrně velká pozornost je $\mathrm{v}$ kontextu badatelsky orientované výuky věnována znalostem učitele, např. L. Katz, K. Sadler a D. V. Craig (2005) nebo O. Lee, J. E. Hart, P. Cuevas a C. Enders (2004) vnímají znalosti učitelů jako součást nezbytných kompetencí. Prvořadě se autoři zaměřují na odborné znalosti související s obsahem vzdělávání. Výstižně požadavek na osvojení si znalostí tohoto typu formulují E. Alake Tuenter, H. J. A. Biemans, H. Tobi a kol. (2012, s. 2617), když uvádí: „učitelé nemohou učit to, co nechápou.“ „Bez komplexního zvládnutí obsahu nemohou úspěšně učit. Hluboké a komplexni pochopeni obsahu prírodnich věd zahrnuje zmapováni a porozuměni faktı̊m a pojmům, pochopeni vztahů mezi pojmy a znalost kdy, jak a vjakém kontextu je použit" (srov. Glen, Dotger, 2009; Leonard, Boakes, Moore, 2009). 
Doceňován je i význam didaktických znalostí, které propojují odborné znalosti s pedagogikou (Avraamidou a Zembal-Saul, 2010; Davis, 2005). Za podstatný lze vymezit př́nos autorů P. L. Grossman (1990) a S. Magnusson, J. Krajcik a H. Borko (1999), kteří vymezují se zaměřením na př́rodovědné obory následující složky didaktických znalostí: orientace ve výuce př́rodovědných předmětů, znalost kurikula, znalost hodnocení, znalost žákova porozumění vědě a znalost výukových strategií.

Celá řada autorů rozpracovává znalosti učitelů související s designováním výuky, např. C. T. Forbes a E. A. Davis (2010) užívají pojem ,pedagogical design capacity“. Učitelé jsou $\mathrm{v}$ jejich pojetí designéři výuky, kteří $\mathrm{k}$ tomuto musí mít osvojené kompetence. Jak zmínění autoři uvádějí, učitelé mají tendenci připravovat a realizovat výuku na základě svých přesvědčení o tom, co dobrého by mělo přírodovědné vzdělávání zahrnovat. Znalostmi spojenými s designováním výuky se ve svých pracích zabývali C. T. Forbes a E. A. Davis (2010), S. M. Glynn a L. K. Winter (2004) nebo S. Marble (2007). Zmiňují, že přípravu výuky učitelé začínají výběrem a přizpůsobením kurikulárních materiálů.

\section{Cíle výzkumu}

V této práci navazujeme na výsledky prvního dílč́iho výzkumného šetření, jehož cílem bylo vhodnými postupy vymezit kompetence učitelů technických a prírodovědných předmětů $\mathrm{k}$ realizaci badatelsky orientované výuky na základních školách a jehož výsledky jsou dostupné v práci J. Dostála (2015).

Cílem v tomto článku prezentovaného výzkumného šetření bylo zjistit vlastnosti navrženého souboru kompetencí, resp. určit, které kompetence učitelů technických a prírodovědných předmětů jsou důležité pro realizaci badatelsky orientované výuky na základních školách. V této souvislosti bylo taktéž podstatné určit, které ze zkoumaných individuálních předpokladů učitelů jsou považovány za významné součásti vymezených kompetencí důležitých pro realizaci badatelsky orientované výuky. Cílem je rovněž na základě získaných výsledků sestavit kompetenční model.

Výzkumná otázka zní: Které kompetence k realizaci badatelsky orientované výuky na základních školách jsou pro učitele technických a př́rodovědných předmětů důležité, a které zkoumané individuální předpoklady považují za podstatné?

Výše uvedeného cíle hodláme dosáhnout řešením následujících dílčích problémů, které budeme dále pro přehlednost označovat jako $\mathrm{A}, \mathrm{B}$ a $\mathrm{C}$.

Problém A: Na které zkoumané individuální předpoklady kladou učitelé technických a př́rodovědných předmětů (experti) na základních školách $\mathrm{v}$ souvislosti s badatelsky orientovanou výukou důraz?

Pro problém $\mathrm{B}$ formulujeme následující výzkumné hypotézy:

H1: Učitelé kladou shodný důraz na individuální předpoklady kategorií typu znalost, dovednost a postoj.

H2: Mezi pořadími u jednotlivých individuálních předpokladů učitelů typu znalost, dovednost a postoj při seřazení dle důležitosti existují rozdíly.

Problém C: Vyskytují se mezi respondenty skupiny závislé na věku, místě školy, kde působí atd., které mají na předmět výzkumu statisticky významně rozdílné názory?

V této souvislosti formulujeme následující výzkumné hypotézy:

H3: Mezi učiteli mladšími 35 let a učiteli staršími 35 let existují rozdíly v názorech na význam jednotlivých individuálních předpokladů. 
H4: Mezi učiteli muži a ženami existují rozdíly v názorech na význam jednotlivých individuálních předpokladů.

H5: Mezi učiteli $\mathrm{z}$ městských škol a učiteli $\mathrm{z}$ vesnických škol existují rozdíly v názorech na význam jednotlivých individuálních předpokladů.

\section{Použité metody}

Zkoumání vlastností teoretického návrhu kompetenčního modelu v rámci druhého dílčího výzkumného šetření bylo žádoucí provádět prostřednictvím metod, které nepracují s velkým vzorkem respondentů, zato však umožnují nahližžet na předmět výzkumu z různých hledisek. Tomuto požadavku plně vyhovovala Q-metodologie (Pelikán, 2004, s. 138 - 143). Q-metodologie spočívá v kombinaci raitingových, psychometrických a statistických procedur, sloužících nejen ke zjištování vyjádření respondentů (Q-shorters), ale i ke zjištování korelace mezi reakcemi či odpověd’mi různých respondentů na předkládané Q-typy (Chráska, 2007).

W. Stephenson (1953) prezentoval Q-metodologii jako opak běžné faktorové analýzy $\mathrm{v}$ tom smyslu, že jsou korelovány osoby na místo testů (testových položek) - běžně je zapotřebí velký počet respondentů (P-sets), kterým je předložen relativně malý počet položek. $\mathrm{V}$ př́padě Q-metodologie tedy postačuje malý počet respondentů, kterým je předložen relativně velký počet testových položek (Q-typů).

Výzkumné šetření probíhá tím způsobem, že jsou respondentům předloženy Q-typy (Q-samples) formou kartiček, nebo dnes již i elektronicky. Q-typy jsou představovány výroky (v tomto výzkumu jednotlivými individuálními předpoklady), které mohou vzejít $\mathrm{z}$ deduktivních úvah, $\mathrm{z}$ publikovaných poznatků, $\mathrm{z}$ rozhovorů atp. $\mathrm{V}$ rámci námi realizovaného výzkumu bylo využito papírových kartiček, na kterých byly výroky natištěny. Počty bývají různé, v našem př́ípadě 120 .

Následuje Q-třídění, kdy respondenti přikládají jednotlivým výrokům určitý význam, což je vyjádřeno umístěním př́islušné kartičky na dané pole $\mathrm{v}$ tř́́dícím archu (matrici). Výsledky třídění jsou zaznamenány a převedeny do elektronické podoby za účelem statistického vyhodnocení.

\section{Popis průběhu výzkumu}

Pro potřeby výzkumu byly ve fyzické podobě připraveny Q-typy, formuláře (trř́dicí archy) a dotazník. Bylo využito tradičního způsobu tř́dění, tj. neelektronické podoby, a v tomto kontextu byly prripraveny podklady pro výzkum.

Všechny vymezené Q-typy byly s ohledem na možnosti statistického zpracování opatřeny čísly. Jelikož by jejich byt' i necílené sdělení respondentům spolu s Q-typy působilo negativně, ve smyslu ovlivnění jejich rozhodování při rozřazování kartiček, byla proto čísla umístěna na rubovou stranu, což znemožnilo jejich viditelnost.

Formulář (trŕdicí arch) obsahoval jedenáct polí, do kterých bylo možné umístit povolené počty kartiček (Q-typů): 4, 6, 10, 13, 17, 20, 17, 13, 10, 6, 4. Dále obsahoval instrukci, která představovala tř́́dicí kritérium: Roztřid'te jednotlivé kompetence podle toho, jak moc se domníváte, že by jimi měl učitel technických a prírodovědných předmětů disponovat, aby byl schopen realizovat badatelsky orientovanou výuku na základní škole.

Podoba tohoto kritéria byla vytvářena společně s pěti učiteli, kteří byli součástí výzkumného vzorku. Hlavní důraz byl kladen na srozumitelnost pro učitele z praxe, 
ze kterých byl výzkumný vzorek složen. V průběhu společného rozhovoru formou expertního panelu došlo $\mathrm{k}$ finální formulaci kritéria.

Součástí každého tř́idicího archu byl dotazník, který měl za cíl umožnit od respondentů získat nezbytné údaje pro potřeby provedení statistických testů, mj. věk, pohlaví, počet let pedagogické praxe a místo, kde se škola, na níž respondent pracuje, nachází. Dotazník byl anonymní. Součástí dotazníku bylo rovněž poskytnutí prostoru respondentům vyjádřit své dosavadní zkušenosti, připomínky či názory na zkoumanou oblast, a možnost vyjádřit se, zdali pochopili všechna z uvedených tvrzení.

Výzkumný vzorek byl volen s ohledem na řešený problém, vymezený cíl a stanovený předpoklad a hypotézy. Jelikož byla zvolena Q-metodologie, bylo prováděno šetření na různých místech, 34 expertů prijielo na naše výzkumné pracoviště a 20 expertů jsme navštívili v místě jejich profesního působení. Povaha zvolené výzkumné metody vyžadovala osobní kontakt výzkumníka s respondentem, který byl instruován o smyslu výzkumu, jeho cílech, způsobu vyplnění dotazníku a o principu Q-třídění. Ukázalo se, že osobní kontakt výzkumníka s respondentem je nutný i pro potřeby správného záznamu výsledků tř́́dění.

Experti byli předem vybráni na základě vyplněného dotazníku, který se zaměřoval na ověřování skutečností jako je délka praxe, potřebná kvalifikace, zda se považuje za uznávaného kolegy a rozsah znalostí ve svém předmětu. Při posuzování skutečnosti, zda daný učitel spadá do kategorie „expert“ bylo využito prací autorů R. Švaříčka (2006), J. Průchy a kol. (2009) a D. R. Cruickshank a D. Haefele (2001). Autoři D. R. Cruickshank a D. Haefele (2001, s. 28) v souladu s autory R. Steinberg a J. Horvath (1995) uvádějí, že učitelé experti se liší od ostatních ve třech oblastech:

- mají rozsáhlé a aplikovatelné znalosti připravené pro využití při vyučování;

- jsou efektivní a jsou schopni udělat více $v$ kratším čase;

- jsou schopni dospět k novým a vhodným řešením problémů.

R. Švaříček (2006, s. 3) považuje za experta učitele následujících parametrů:

- má minimálně 10 let praxe;

- má potřebnou kvalifikaci/diplom pro výkon povolání;

- je označen za experta vedením školy (ředitelem a zástupci);

- je uznáván kolegy (pro výkony a zastávané hodnoty), což jej odlišuje od odborníka;

- má velké znalosti svého předmětu.

Uvedené parametry se pro nás staly výchozími, avšak hranici 10 let jsme v souladu s J. Průchou a kol. (2009) a M. Píšovou (2010) snížili na 5 let. Dle J. Průchy a kol. (2009, s. 398) se učitel expertem stává asi po pěti a více letech výkonu profese. M. Píšová $(2010$, s. 53) v souladu s D. J. Palmer a kol. (2005) uvádí, že jedním $\mathrm{z}$ indikátorů expertnosti je délka zkušenosti $\mathrm{v}$ profesi a $\mathrm{v}$ tomto kontextu vymezují obvyklou dobu 5 až 10 let praxe.

Dotazník pro identifikaci expertů a navázání kontaktu s nimi, viz př́loha č. 9 , byl distribuován na základní školy v Olomouckém kraji. Konkrétně se jednalo o 156 základních škol s 1. - 9. ročníkem. Zaslán byl k rukám vedení školy a návratnost dosáhla hodnoty 85 vyplněných dotazníků ze 156 odeslaných. Následným telefonickým a e-mailovým kontaktováním se však pro další spolupráci, jejímž výsledkem byla účast na výzkumu prostřednictvím Q-metodologie, podařilo získat pouze 54 učitelů expertů.

Výzkum probíhal v únoru až červnu roku 2013. Přehled struktury výzkumného vzorku je patrný z následující tabulky: 


\begin{tabular}{|c|c|c||c|c|c|}
\hline Pohlaví & Četnost & $\begin{array}{c}\text { Relativní } \\
\text { četnost (\%) }\end{array}$ & $\begin{array}{c}\text { Věková } \\
\text { struktura }\end{array}$ & Četnost & $\begin{array}{c}\text { Relativní } \\
\text { četnost (\%) }\end{array}$ \\
\hline Ženy & 30 & 55,6 & $21-30$ let & 8 & 14,82 \\
\hline Muži & 24 & 44,4 & $31-40$ let & 41 & 75,93 \\
\hline Celkem & 54 & 100 & $41-50$ let & 5 & 9,26 \\
\hline
\end{tabular}

Tabulka č. 1: Struktura výzkumného vzorku

\section{Výsledky výzkumného šetření}

Dřive, nežli jsme přistoupili k prezentaci naměřených výsledků, posoudili jsme míru spolehlivosti a presnosti, tj. reliabilitu použitého měřicího nástroje. K ověření, zda měření bylo reliabilní, jsme použili výpočet Cronbachova koeficientu alfa, který posuzuje vniťrní konzistenci a pro potvrzení tohoto výpočtu byla použita také metoda půlení (Split-half).

\begin{tabular}{|l|l|}
\hline Metoda ověření & Vypočítaná reliabilita \\
\hline Cronbachovo alfa & 0,97 \\
\hline Metoda půlení & 0,95 \\
\hline
\end{tabular}

Tabulka č. 2: Reliabilita dotazníku

Výsledky analýzy spolehlivosti uvedené v tabulce č. 2 potvrdily dostatečně vysokou reliabilitu. V obou př́padech je hodnota výrazně vyšší než minimální požadovaná hranice 0,70 v prrípadě Klinova pravidla nebo 0,94 v případě Helmstaderova pravidla, což prokazuje velmi vysokou spolehlivost naměřených výsledků.

\subsection{Testování výzkumného předpokladu $V_{P_{1}}$}

Pro dílčí problém A byl formulován výzkumný předpoklad:

$\mathbf{V P}_{1:}$ Mezi deset nejdůležitějších kompetencí pro realizaci badatelsky orientované výuky budou patřit následující:

- Propojit badatelské aktivity s praktickým životem;

- Motivovat žáky k učení prostřednictvím badatelských aktivit;

- Rozvíjet prostřednictvím badatelských aktivit myšlení žáků;

- Demonstrovat badatelské aktivity žákům;

- Zajistit bezpečnost při realizaci badatelských aktivit;

- Interpretovat průběh a výsledky badatelských aktivit.

Pro potřeby ověření platnosti výzkumného předpokladu bylo využito již zmíněné Q-metodologie a učitelům byl předložen soubor Q-typů (kompetencí) v podobě individuálních předpokladů. Tři předpoklady, tj. jeden typu znalost, druhý typu dovednost a třetí typu postoj, se vždy vztahovaly k jedné kompetenci.

Q-typy byly roztř́děny tak, že byly $\mathrm{k}$ dané kompetenci vždy přiřazeny související individuální předpoklady typu znalost, dovednost a postoj. Do uspořádání Q-typů $\mathrm{v}$ podobě tabulky byly doplněny průměry vyjadřující důležitost daného individuálního předpokladu. Tato skutečnost nám ještě neumožňovala s dostatečnou mírou validity rozhodnout o platnosti výzkumného předpokladu, jelikož jednotlivé průměry měly různé hodnoty, které zapríičinoovaly různé pořadí dané kompetence. Proto byly vypočteny celkové prüměry pro jednotlivé kompetence a na jejich základě byly 
kompetence setř́děny dle celkových průměrů sestupně. Pořadí deseti nejlépe hodnocených kompetencí je zřetelné z grafu č. 1 .

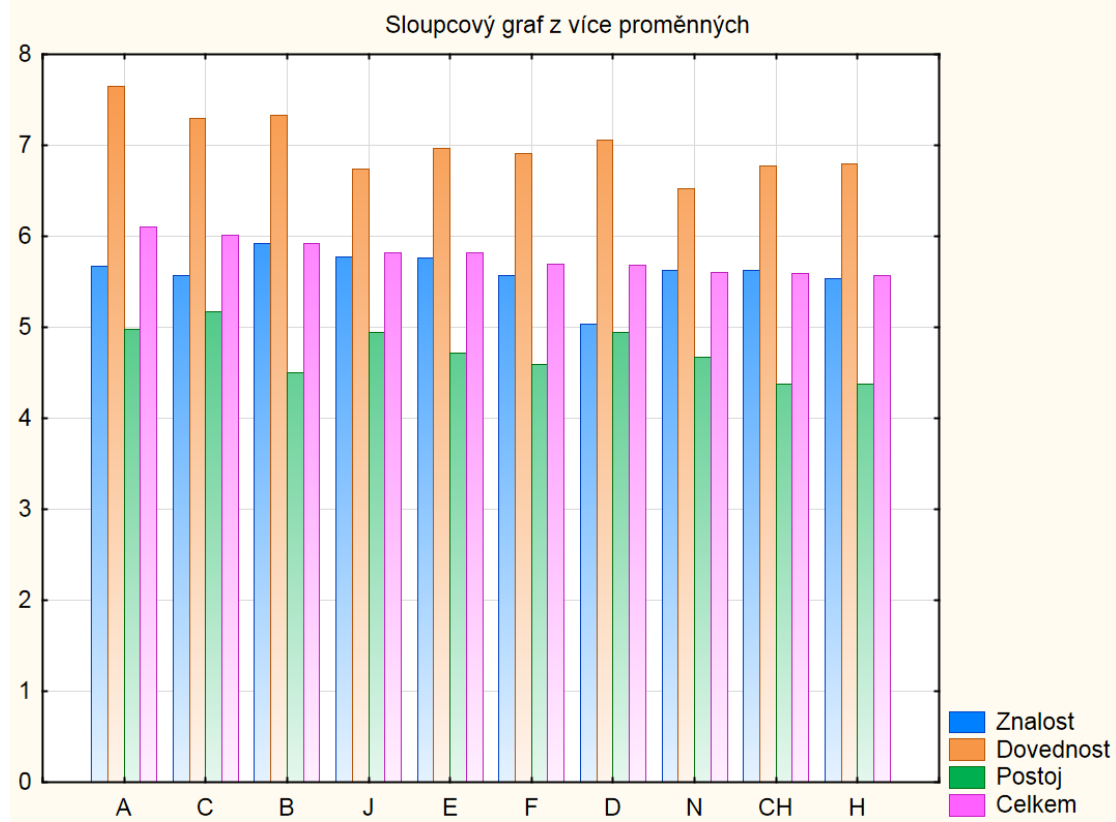

Graf č. 1: Zobrazení deseti nejdůležitějšisich kompetencí (dle průměrných hodnot)

Výsledky výzkumu $k$ ověření formulovaného výzkumného předpokladu $\mathbf{V P}_{\mathbf{1}}$ lze shrnout takto: z grafu č. 1 znázorňujícího selektovaných deset nejdůležitějších kompetencí, lze vyčíst, že mezi nejdůležitěji hodnocené patří (uvedeno sestupně) kompetence označené $\mathrm{A}, \mathrm{C}, \mathrm{B}, \mathrm{J}, \mathrm{E}, \mathrm{F}, \mathrm{D}, \mathrm{N}, \mathrm{CH}$ a H, tj.:

- A - Motivovat žáky $\mathrm{k}$ učení prostřednictvím badatelských aktivit.

- C - Propojit badatelské aktivity s praktickým životem.

- B - Demonstrovat badatelské aktivity žákům.

- J - Interpretovat průběh a výsledky badatelských aktivit.

- E - Zajistit bezpečnost při realizaci badatelských aktivit.

- F - Rozvíjet samostatné objevování poznatků žáky prostřednictvím badatelských aktivit.

- D - Rozvíjet prostřednictvím badatelských aktivit myšlení žáků.

- $\mathrm{N}$ - Realizovat badatelské aktivity v návaznosti na dosavadní znalosti a představy žáků.

- $\mathrm{CH}$ - Rozvíjet představivosti prostřednictvím badatelských aktivit žáků.

- H - Propojit badatelské aktivity s teorií. 
Komparujeme-li výzkumem zjištěný soubor deseti nejdůležitějších kompetencí s šesti kompetencemi obsaženými ve výzkumném předpokladu $\mathrm{VP}_{1}$, docházíme k závěru, že tento předpoklad lze považovat za potvrzený.

\subsection{Testování hypotézy $\mathrm{H}_{1}$}

Hypotéza $\mathrm{H}_{1}$ se zaměřuje na zjištění skutečnosti, zda učitelé technických a prrírodovědných předmětů kladou shodný důraz na individuální předpoklady typu znalost, dovednost a postoj, nebo zda mezi nimi existují nějaké rozdíly.

Pro dílčí problém $\mathrm{B}$ byla formulována hypotéza:

$\mathbf{H}_{1}$ : Učitelé kladou shodný důraz na individuální předpoklady kategorí typu znalost, dovednost a postoj.

Při ověřování platnosti hypotézy $H_{1}$ vycházíme $\mathrm{z}$ předpokladu, že $\mathrm{v}$ př́ípadě, že by učitelé kladli na všechny typy stejný důraz, byly by ve výsledném pořadí dle důležitosti individuální předpoklady daných typů rozvrstveny rovnoměrně. Za tímto účelem jsme soubor všech sto dvaceti individuálních předpokladů rozdělili na tři dílčí soubory A, B a C, vždy po čtyřiceti. Počet dílčích souborů by mohl být teoreticky libovolný, my jsme však vycházeli ze struktury celkového souboru a naměřených výsledků. V takto vzniklých souborech budeme testovat, zda jsou četnosti Q-typů př́islušejících $\mathrm{k}$ př́ślušné kategorii zastoupeny rovnoměrně, tedy ve stejném počtu, nebo zdali se naměřené počty statisticky významně liší od teoretických. K ověřování bude využito testu dobré shody chí-kvadrát.

Pro potřeby testování skupiny Q-typů A byly formulovány nulová $\mathrm{H}_{0}$ a alternativní $\mathrm{H}_{\mathrm{A}}$ hypotéza:

$\mathrm{H}_{0}$ : Četnosti individuálních předpokladů všech kategorií (znalost, dovednost, postoj) jsou v souboru A stejné.

$\mathrm{H}_{\mathrm{A}}$ : Četnosti individuálních předpokladů všech kategorií (znalost, dovednost, postoj) jsou v souboru A rozdílné.

Analýzou údajů dospíváme pro Q-typy v pořadí 1 - 40 k níže uvedeným četnostem.

\begin{tabular}{|c|c|c|c|}
\hline \multicolumn{4}{|c|}{ Četnosti skupiny Q-typů A } \\
\hline Celkem & Kategorie znalost & Kategorie dovednost & Kategorie postoj \\
\hline 40 & 11 & 29 & 0 \\
\hline
\end{tabular}

Tabulka č. 3: Četnosti skupiny Q-typi̊ A

Následovalo testování prostřednictvím testu dobré shody chí-kvadrát. Vypočítaná hodnota $\chi^{2}=32,15$. Provedeme-li srovnání s hodnotou kritickou, přijímáme alternativní hypotézu. Př́i analýze jednotlivých Q-typů obsažených $\mathbf{v}$ souboru A bylo zjištěno, že dominují dovednosti, méně jsou pak zastoupeny znalosti. Učitelé tedy v první třetině nejdůležitějších Q-typů kladou důraz na dovednosti.

Pro potřeby testování skupiny Q-typů $\mathrm{B}$ byly formulovány nulová $\mathrm{H}_{0}$ a alternativní $\mathrm{H}_{\mathrm{A}}$ hypotéza:

$\mathrm{H}_{0}$ : Četnosti individuálních předpokladů všech kategorií (znalost, dovednost, postoj) jsou v souboru B stejné.

$\mathrm{H}_{\mathrm{A}}$ : Četnosti individuálních předpokladů všech kategorií (znalost, dovednost, postoj) jsou v souboru B rozdílné.

Z údajů zjištujeme, že Q-typy v pořadí $41-80$ mají v jednotlivých kategoriích následující četnosti. 


\begin{tabular}{|c|c|c|c|}
\hline \multicolumn{4}{|c|}{ Četnosti skupiny Q-typů B } \\
\hline Celkem & Kategorie znalost & Kategorie dovednost & Kategorie postoj \\
\hline 40 & 23 & 8 & 9 \\
\hline
\end{tabular}

Tabulka č. 4: Četnosti skupiny Q-typio B

Proběhlo testování prostřednictvím testu dobré shody chí-kvadrát. Vypočítaná hodnota $\chi^{2}=10,55$. Provedeme-li srovnání s hodnotou kritickou, přijímáme alternativní hypotézu.

Při analýze jednotlivých Q-typů obsažených v souboru B bylo zjištěno, že dominují znalosti, méně jsou pak zastoupeny postoje a dovednosti. Učitelé tedy v druhé třetině Q-typů seřazených podle důležitosti kladou důraz na znalosti.

Pro potřeby testování skupiny Q-typů $\mathrm{C}$ byly formulovány nulová $\mathrm{H}_{0}$ a alternativní $\mathrm{H}_{\mathrm{A}}$ hypotéza:

$\mathrm{H}_{0}$ : Četnosti individuálních předpokladů všech kategorií (znalost, dovednost, postoj) jsou v souboru C stejné.

$\mathrm{H}_{\mathrm{A}}$ : Četnosti individuálních předpokladů všech kategorií (znalost, dovednost, postoj) jsou v souboru C rozdílné.

Z analýzy údajů vyplývá, že Q-typy v pořadí 81 - 120 mají vjednotlivých kategoriích následující četnosti.

\begin{tabular}{|c|c|c|c|}
\hline \multicolumn{4}{|c|}{ Četnosti skupiny Q-typů C } \\
\hline Celkem & Kategorie znalost & $\begin{array}{c}\text { Kategorie } \\
\text { dovednost }\end{array}$ & Kategorie postoj \\
\hline 40 & 6 & 3 & 31 \\
\hline
\end{tabular}

Tabulka č. 5: Četnosti skupiny Q-typů C

Následovalo testování s využitím testu dobré shody chí-kvadrát. Vypočítaná hodnota $\chi^{2}=35,45$. Provedeme-li srovnání s hodnotou kritickou, přijímáme alternativní hypotézu. Při analýze jednotlivých Q-typů obsažených v souboru $C$ bylo zjištěno, že dominují postoje, méně jsou pak zastoupeny znalosti a dovednosti. Učitelé tedy ve třetí třetině nejméně důležitých Q-typů kladou důraz na postoje.

Ve všech třech př́padech byly výsledky testování statisticky významné, což znamená, že je nelze vysvětlovat na základě náhody. Jelikož testování pro skupiny A, B a C probíhalo z principu odděleně, jevilo se jako prrínosné vytvořit graf č. 2 zachycující výsledky ve všech třech skupinách současně. Na grafu si lze povšimnout, že ve skupině A, zahrnující nejdůležitější Q-typy, se nenachází žádné postoje, v menší míre pak znalosti. Výzkumně se podařilo prokázat, že převaha dovedností je statisticky významná. Ve skupině B statisticky významně převládají znalosti, oproti dovednostem a postojům. V poslední skupině označené jako C a zahrnující nejméně důležité Q-typy, převažují postoje, opět na statisticky významné úrovni. Z uvedeného dedukujeme otázku: co je př́íčinou tohoto stavu?

Odpověd' na tuto otázku jsme hledali v logických úvahách i za pomocí rozhovorů se zkoumanými pedagogy. Nelze jednoznačně usuzovat, že by některý z předpokladů, at' již znalost, dovednost nebo postoj byl významnější, jelikož působí ve vzájemné integritě. Osvojení si dovedností předpokládá využití znalostí, stejně tak bez kladného 
postoje se dovednost nemusí projevit. Nicméně výzkum prokázal zvýšený důraz na dovednosti, a proto jsme pokračovali ve výzkumu oslovením 10 respondentů zahrnutých ve výzkumu prostřednictvím Q-metodologie, se kterými byl proveden rozhovor.

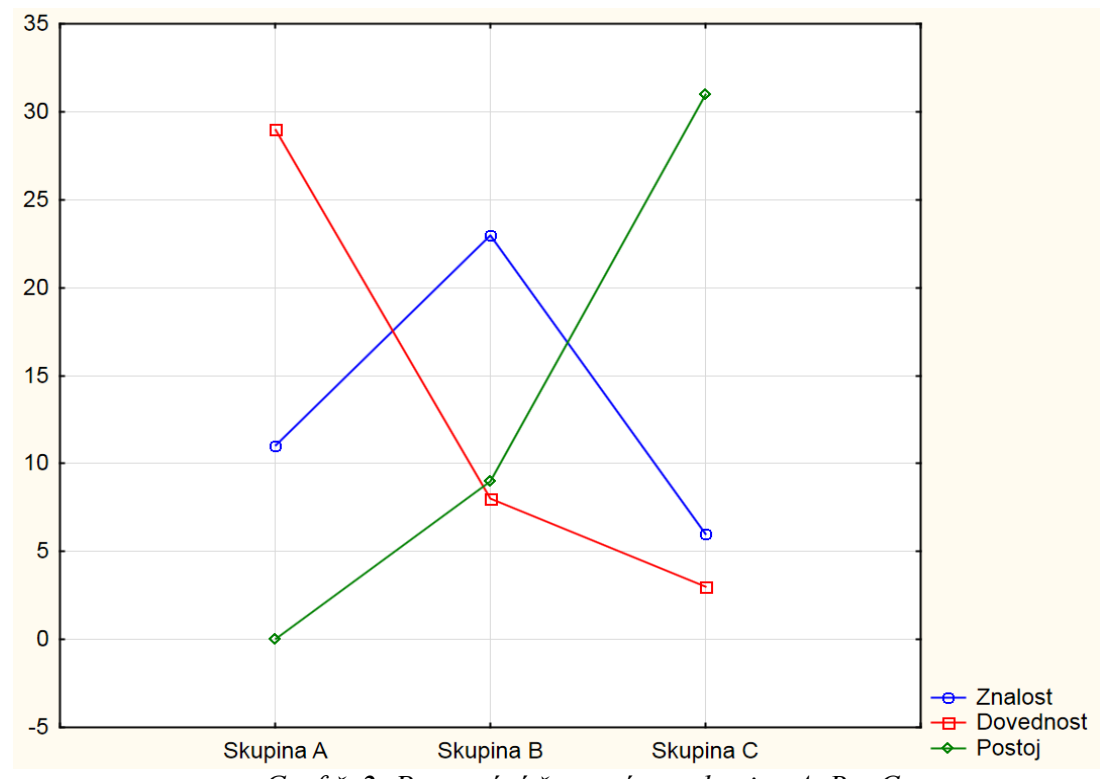

Grafč. 2: Porovnání četností pro skupiny A, $B$ a $C$

Respondentům byly poskytnuty výsledky šetření a byli požádání o zdůvodnění tohoto zjištění. Rozhovory poskytly vysvětlení, že dovednosti vnímají učitelé jako nejpodstatnější. Tuto skutečnost vyjádřil jeden z učitelů následovně „neni dưležité vědět jak učit či chtít učit, praxe vyžaduje, aby učitel uměl učit. "Učitelé experti tímto při výzkumu prostřednictvím Q-metodologie vyjadřovali (aniž by o tom přímo uvažovali) že některé individuální předpoklady mají v rámci kompetencí podmiňující charakter, tzn., že je možné mít znalosti bez dovedností, avšak dovednosti bez znalostí dost dobře existovat nemohou. Akcentací dovedností se projevil požadavek, že učitel, aby mohl provádět badatelsky orientovanou výuku, musí dospět do dovednostní fáze. Hypotéza $\mathrm{H}_{1}$ ve znění Učitelé kladou shodný dưraz na individuální předpoklady kategorii typu znalost, dovednost a postoj nebyla dokázána.

\subsection{Testování hypotézy $\mathrm{H}_{2}$}

Hypotéza $\mathrm{H}_{2}$ se zaměřuje na posouzení homogennosti v hodnocení kompetencí experty. Jak již bylo zdůvodněno, v rámci výzkumu se orientujeme na tři individuální předpoklady: znalost, dovednost a postoj. Každá zkoumaná kompetence zahrnovala všechny tři kategorie v podobě Q-typů. Pokud učitelé $\mathrm{k}$ výzkumu přistupovali zodpovědně, měly by se Q-typy druhu znalost, dovednost a postoj, vždy příslušející 
$\mathrm{k}$ jedné kompetenci, umístit při seřazení dle důležitosti $\mathrm{v}$ ideálním př́padě na shodné úrovni.

Pro dílčí problém $\mathrm{D}$ byla formulována hypotéza $\mathrm{H}_{2}$ :

Mezi pořadími u jednotlivých individuálních př̀edpokladů učitelů typu znalost, dovednost a postoj při seřazení dle důležitosti existují rozdíly.

Pro potřeby testování byly formulovány nulová $\mathrm{H}_{0}$ a alternativní $\mathrm{H}_{\mathrm{A}}$ hypotéza:

$\mathrm{H}_{0}$ : Vypočítaná hodnota Spearmanova koeficientu nevypovídá o shodě mezi hodnocením jednotlivých Q-typů.

$\mathrm{H}_{\mathrm{A}}$ : Vypočítaná hodnota Spearmanova koeficientu vypovídá o shodě mezi hodnocením jednotlivých Q-typů.

Postup:

Při ověřování platnosti hypotézy jsme postupovali následujícím způsobem. Nejdřive byly jednotlivé Q-typy kategorizovány podle kritéria do tř́ skupin, tj. zda př́isluší mezi znalosti, dovednosti nebo postoje. Tř́ílěním a následným sestupným seřazením podle důležitosti nám vznikly skupiny. $Z$ údajů vyplynulo, že Q-typy druhu znalost, dovednost a postoj, vždy př́slušející $\mathrm{k}$ jedné kompetenci, jsou na stejné úrovni pouze $\mathrm{v}$ jednom př́ípadě. Zajímalo nás ale, jak moc jsou ostatní Q-typy rozptýleny a zda existuje souvislost mezi jednotlivými pořadími.

To, zda spolu jednotlivé kategorie z hlediska pořadí Q-typů navzájem souvisí, bylo ověřováno Spearmanovým koeficientem pořadové korelace.

Výsledek:

\begin{tabular}{|l|c|c|c|}
\hline \multicolumn{5}{|c|}{ Spearmanovy korelace } \\
*Označené korelace jsou významné na hladině význ. p <0,050 \\
\hline Znalost & Znalost & Dovednost & Postoj \\
\hline Dovednost & 1,00 & 0,74 & 0,84 \\
\hline Postoj & 0,74 & 1,00 & 0,78 \\
\hline
\end{tabular}

Tabulka č. 6: Výpočet Spearmanova koeficientu pořadové korelace

Ve všech př́padech bylo prokázáno, že korelace souborů jsou statisticky významné. Pořadí vytvořená tř́íděním $Q$-typů $\mathrm{v}$ kategoriích znalost, dovednost a postoj si vzájemně odpovídají. Hypotéza $\mathrm{H}_{2}$ nebyla dokázána. Respondenti tedy přikládají kompetencím rozpracovaným do uvedených oblastí statisticky shodnou míru důležitosti.

\subsection{Testování hypotézy $\mathbf{H}_{3}$}

Z tabulky č. 1 je zřetelné, že výzkumný vzorek byl složen z respondentů různého věku. Abychom vyloučili vliv věku na dosažené výsledky a prokázali tak nezávislost výsledků na tomto faktoru, stanovili jsme hypotézu $\mathrm{H}_{3}$ a provedli její testování. $\mathrm{K}$ tomu bylo využito statistické metody výpočtu Spearmanova koeficientu. Pro určení možných dílčích rozdílů mezi skupinami respondentů byl dále použit Studentův t-test.

Výzkumný vzorek jsme pro potřeby testování rozdělili na dvě skupiny, na mladší učitele, které jsme ohraničili 35 lety (včetně) a na učitele starší, nad 35 let.

Hypotéza $\mathrm{H}_{3}$

Mezi učiteli mladšími 35 let a učiteli staršími 35 let existují rozdíly v názorech na význam jednotlivých individuálních předpokladů. 
Pro testování platnosti hypotézy byly zformulovány nulová a alternativní hypotéza:

$\mathrm{H}_{0 \text { : }}$ Pořadí důležitosti Q-typů u učitelů mladších 35 let a u učitelů starších 35 let není rozdílné.

$\mathrm{H}_{\mathrm{A}}$ Pořadí důležitosti Q-typů u učitelů mladších 35 let a u učitelů starších 35 let je rozdílné.

Postup:

Formulovanou hypotézu jsme ověrovali na vzorku respondentů pomocí výpočtu Spearmanova koeficientu pořadové korelace. Pro určení možných dílčích rozdílů mezi skupinami respondentů byl dále použit Studentův t-test. Grupovací proměnou byl věk respondentů.

Výsledek:

Vypočtená hodnota Spearmanova koeficientu pořadové korelace $\mathbf{r}_{\mathbf{s}}=\mathbf{0 , 8 7}$ vypovídá o vysoké závislosti hodnocení oběma porovnávanými skupinami učitelů. Nelze tedy odmítnout nulovou hypotézu, že pořadí důležitosti Q-typů u učitelů mladších 35 let (S1) a u učitelů starších 35 let (S2) není rozdílné. Platnost hypotézy $\mathrm{H}_{3}$ tedy nebyla potvrzena. Na základě provedených analýz můžeme potvrdit, že hodnocení zkoumaných Q-typů učiteli je celkově nezávislé na věku respondentů.

\subsection{Testování hypotézy $\mathrm{H}_{4}$}

Výzkumný vzorek byl složen z respondentů různého pohlaví, viz tabulka č. 1 . Abychom vyloučili vliv pohlaví respondenta na dosažené výsledky, a prokázali tak nezávislost výsledků na tomto faktoru, stanovili jsme hypotézu $\mathrm{H}_{4}$ a provedli testování. K tomu bylo využito statistické metody výpočtu Spearmanova koeficientu. Pro určení možných dílčích rozdílů mezi skupinami respondentů byl dále použit Studentův t-test.

Hypotéza $\mathrm{H}_{4}$

Mezi učiteli muži a ženami existují rozdíly v názorech na význam jednotlivých individuálních předpokladů.

Pro testování platnosti hypotézy byly zformulovány nulová a alternativní hypotéza:

$\mathrm{H}_{0:}$ Pořadí důležitosti Q-typů u učitelů mužů a učitelů žen není rozdílné.

$\mathrm{H}_{\mathrm{A}}$ Pořadí důležitosti Q-typů u učitelů mužů a učitelů žen je rozdílné.

Postup:

Formulovanou hypotézu jsme ověrovali na vzorku respondentů pomocí výpočtu Spearmanova koeficientu pořadové korelace. Pro určení možných dílčích rozdílů mezi skupinami respondentů byl dále použit Studentův t-test. Grupovací proměnou bylo pohlaví respondentů.

Výsledek:

Vypočtená hodnota Spearmanova koeficientu pořadové korelace $\mathbf{r}_{\mathrm{s}}=\mathbf{0 , 8 4}$ vypovídá o vysoké závislosti hodnocení oběma porovnávanými skupinami učitelů. Nelze tedy odmítnout nulovou hypotézu. Tento výsledek je možné interpretovat tak, že pořadí důležitosti Q-typů u učitelů žen a učitelů mužů není rozdílné. Hypotéza $\mathbf{H}_{4}$ nebyla potvrzena.

Testování vlivu pohlaví na výsledky bývá předmětem diskuzí v souvislosti s problematikou genderu. Spíše nežli testování samotné je podstatná interpretace výsledků testování. V našem př́ípadě se prokázalo, že pohlaví respondenta nemá vliv na výsledky.

Na základě provedených analýz můžeme konstatovat, že hodnocení zkoumaných Q-typů učiteli je celkově nezávislé na pohlaví respondentů. 


\subsection{Testování hypotézy $\mathrm{H}_{5}$}

Při testování jsme se zaměřili i na posouzení možného vlivu způsobeného tím, kde se škola nachází, tj. zda se jedná o městskou školu, nebo školu vesnickou. Abychom vyloučili vliv tohoto faktoru na dosažené výsledky a prokázali tak nezávislost výsledků, stanovili jsme hypotézu $\mathrm{H}_{5}$ a provedli testování. $\mathrm{K}$ tomu bylo využito statistické metody výpočtu Spearmanova koeficientu. Pro určení možných dílčích rozdílů mezi skupinami respondentů byl dále použit Studentův t-test.

Hypotéza $\mathrm{H}_{5}$

Mezi učiteli z městských škol a učiteli z vesnických škol existují rozdíly v názorech na význam jednotlivých individuálních předpokladů.

Pro testování platnosti hypotézy byly zformulovány nulová a alternativní hypotéza:

$\mathrm{H}_{0 \text { : }}$ Pořadí důležitosti Q-typů u učitelů $\mathrm{z}$ městských škol a učitelů $\mathrm{z}$ vesnických škol není rozdílné.

$\mathrm{H}_{\mathrm{A}}$ : Pořadí důležitosti Q-typů u učitelů z městských škol a učitelů z vesnických škol je rozdílné.

Postup:

Formulovanou hypotézu jsme ověřovali na vzorku respondentů pomocí výpočtu Spearmanova koeficientu pořadové korelace a dále Studentova $\mathrm{t}$-testu pro nezávislé skupiny. Grupovací proměnou byla skutečnost, zda se jedná o městskou školu, nebo vesnickou.

Výsledek:

Vypočtená hodnota Spearmanova koeficientu pořadové korelace $\mathbf{r}_{\mathrm{s}}=\mathbf{0 , 8 1}$ vypovídá o vysoké závislosti hodnocení oběma porovnávanými skupinami učitelů. Nelze tedy odmítnout nulovou hypotézu. Tento výsledek je možné interpretovat tak, že pořadí důležitosti Q-typů u učitelů $z$ městských škol a učitelů z vesnických škol není rozdílné. Platnost hypotézy $\mathrm{H}_{5}$ nebyla potvrzena. Na základě provedených analýz můžeme konstatovat, že hodnocení zkoumaných Q-typů učiteli je celkově nezávislé na skutečnosti, kde se škola nachází.

\subsection{Konstrukce kompetenčního modelu učitele}

S využitím výsledků provedených výzkumných šetření a následného testování můžeme pokročit k vlastní konstrukci kompetenčního modelu učitele $\mathrm{v}$ kontextu badatelsky orientované výuky technických a prŕrodovědných př̌edmětů. Aplikací vhodných výzkumných postupů se podařilo vymezit soubor kompetencí a zjistit jejich vlastnosti, a to jednak kompetencí samotných, ale i celého souboru. Zjiššené vlastnosti nám umožňovaly zahájit další kroky.

Vytvářený kompetenční model budeme členit do tř́i oblastí - na oblast klíčových kompetencí, oblast základních kompetencí a oblast prahových kompetencí. Z našeho pohledu jsou nejpodstatnějši klíčové kompetence, které představují kompetenční jádro. Bez nich by jedinec nebyl schopen badatelsky orientovanou výuku zvládnout a nedosahoval by požadovaných efektů. Vedle klíčových kompetencí se nacházejí základní, které jsou pro badatelsky orientovanou výuku rovněž důležité, avšak nejsou již tolik specifické a jsou přenositelné z obecného rámce učitelských kompetencí. Prahové kompetence jsou značně univerzální a jsou na samé hranici učitelské kompetence. Jejich nezvládnutí je znakem širší nekompetentnosti učitele. 
Na základě získaných výsledkủ je možné s vysokou mírou pravděpodobnosti určit, které kompetence je pro učitele důležité, avšak nejsme schopni adekvátně posoudit, kde se nachází hranice mezi oblastmi klíčových, základních a prahových kompetencí. Proto byli opět kontaktováni náhodně vybraní učitelé (12 učitelů), kteří se účastnili výzkumu. Byli požádáni o rozhovor, jehož výsledkem bude rozčlenění souboru kompetencí na kompetence klíčové, základní a prahové. 5 dnů před rozhovorem byl učitelům poskytnut soubor včetně výsledků hodnocení s požadavkem, aby zhodnotili výsledky provedeného výzkumu a zda s nimi souhlasí. Dále byli požádáni, aby posoudili, které kompetence lze označit za klíčové, základní a prahové a své závěry zaznamenali do archů. Výsledky jsme souhrnně zaznamenali do tabulky č. 7 a barevně odlišili klíčové kompetence zelenou, základní modrou a prahové žlutou barvou.

\begin{tabular}{|c|c|c|c|c|c|c|c|c|c|c|c|}
\hline U1 & U2 & U3 & U4 & U5 & U6 & U7 & U8 & U9 & U10 & U11 & U12 \\
\hline A & A & A & A & A & A & A & A & A & A & A & A \\
\hline $\mathrm{C}$ & $\mathrm{C}$ & $\mathrm{C}$ & $\mathrm{C}$ & $\mathrm{C}$ & $\mathrm{C}$ & $\mathrm{C}$ & $\mathrm{C}$ & $\mathrm{C}$ & $\mathrm{C}$ & $\mathrm{C}$ & $\mathrm{C}$ \\
\hline $\mathrm{B}$ & $\mathrm{B}$ & B & B & B & $\mathrm{B}$ & $\mathrm{B}$ & $\mathrm{B}$ & $\mathrm{B}$ & B & $\mathrm{B}$ & B \\
\hline $\mathrm{J}$ & $\mathrm{J}$ & $\mathrm{J}$ & $\mathrm{J}$ & $\mathrm{J}$ & $\mathrm{J}$ & $\mathrm{J}$ & $\mathrm{J}$ & $\mathrm{J}$ & $\mathrm{J}$ & $\mathrm{J}$ & $\mathrm{J}$ \\
\hline$E$ & $E$ & $\mathrm{E}$ & $E$ & $\mathrm{E}$ & $\mathrm{E}$ & $E$ & $\mathrm{E}$ & $\mathrm{E}$ & $\mathrm{E}$ & $\mathrm{E}$ & $\mathrm{E}$ \\
\hline $\mathrm{F}$ & $\mathrm{F}$ & $\mathrm{F}$ & $\mathrm{F}$ & $\mathrm{F}$ & $\mathrm{F}$ & $\mathrm{F}$ & $\mathrm{F}$ & $\mathrm{F}$ & $\mathrm{F}$ & $\mathrm{F}$ & $\mathrm{F}$ \\
\hline $\bar{D}$ & $\bar{D}$ & $\bar{D}$ & $\bar{D}$ & $\bar{D}$ & $\bar{D}$ & $\mathrm{D}$ & $\bar{D}$ & $\bar{D}$ & $\bar{D}$ & $\bar{D}$ & $\mathrm{D}$ \\
\hline $\mathrm{N}$ & $\mathrm{N}$ & $\mathrm{N}$ & $\mathrm{N}$ & $\mathrm{N}$ & $\mathrm{N}$ & $\mathrm{N}$ & $\mathrm{N}$ & $\mathrm{N}$ & $\mathrm{N}$ & $\mathrm{N}$ & $\mathrm{N}$ \\
\hline $\mathrm{CH}$ & $\mathrm{CH}$ & $\mathrm{CH}$ & $\mathrm{CH}$ & $\mathrm{CH}$ & $\mathrm{CH}$ & $\mathrm{CH}$ & $\mathrm{CH}$ & $\mathrm{CH}$ & $\mathrm{CH}$ & $\mathrm{CH}$ & $\mathrm{CH}$ \\
\hline $\mathrm{H}$ & $\mathrm{H}$ & $\mathrm{H}$ & $\mathrm{H}$ & $\mathrm{H}$ & $\mathrm{H}$ & $\mathrm{H}$ & $\mathrm{H}$ & $\mathrm{H}$ & $\mathrm{H}$ & $\mathrm{H}$ & $\mathrm{H}$ \\
\hline $\mathrm{R}$ & $\mathrm{R}$ & $\mathrm{R}$ & $\mathrm{R}$ & $\mathrm{R}$ & $\mathrm{R}$ & $\mathrm{R}$ & $\mathrm{R}$ & $\mathrm{R}$ & $\mathrm{R}$ & $\mathrm{R}$ & $\mathrm{R}$ \\
\hline $\mathrm{V}$ & $\mathrm{V}$ & $\mathrm{V}$ & $\mathrm{V}$ & $\mathrm{V}$ & $\mathrm{V}$ & $\mathrm{V}$ & $\mathrm{V}$ & $\mathrm{V}$ & $\mathrm{V}$ & $\mathrm{V}$ & $\mathrm{V}$ \\
\hline $\mathrm{P}$ & $\mathrm{P}$ & $\mathrm{P}$ & $\mathrm{P}$ & $\mathrm{P}$ & $\mathrm{P}$ & $\mathrm{P}$ & $\mathrm{P}$ & $\mathrm{P}$ & $\mathrm{P}$ & $\mathrm{P}$ & $\mathrm{P}$ \\
\hline$\overline{\mathrm{U}}$ & $\overline{\mathrm{U}}$ & $\overline{\mathrm{U}}$ & $\overline{\mathrm{U}}$ & $\overline{\mathrm{U}}$ & $\overline{\mathrm{U}}$ & $\overline{\mathrm{U}}$ & $\overline{\mathrm{U}}$ & $\overline{\mathrm{U}}$ & $\overline{\mathrm{U}}$ & $\overline{\mathrm{U}}$ & $\bar{U}$ \\
\hline $\mathrm{O}$ & $\mathrm{O}$ & $\mathrm{O}$ & $\mathrm{O}$ & $\mathrm{O}$ & $\mathrm{O}$ & $\mathrm{O}$ & $\mathrm{O}$ & $\mathrm{O}$ & $\mathrm{O}$ & $\mathrm{O}$ & $\mathrm{O}$ \\
\hline $\mathrm{K}$ & $\mathrm{K}$ & $\mathrm{K}$ & $\mathrm{K}$ & $\mathrm{K}$ & $\mathrm{K}$ & $\mathrm{K}$ & $\mathrm{K}$ & $\mathrm{K}$ & $\mathrm{K}$ & $\mathrm{K}$ & $\mathrm{K}$ \\
\hline$S$ & $\mathrm{~S}$ & $S$ & $S$ & $\mathrm{~S}$ & $\mathrm{~S}$ & $\mathrm{~S}$ & $S$ & $\mathrm{~S}$ & $\mathrm{~S}$ & $\mathrm{~S}$ & $S$ \\
\hline $\mathrm{I}$ & $\mathrm{I}$ & $\mathrm{I}$ & $\mathrm{I}$ & $\mathrm{I}$ & $\mathrm{I}$ & $\mathrm{I}$ & $\mathrm{I}$ & $\mathrm{I}$ & $\mathrm{I}$ & $\mathrm{I}$ & $\mathrm{I}$ \\
\hline $\mathrm{M}$ & $\mathrm{M}$ & $\mathrm{M}$ & $\mathrm{M}$ & $\mathrm{M}$ & $\mathrm{M}$ & $\mathrm{M}$ & $\bar{M}$ & $\mathrm{M}$ & $\mathrm{M}$ & $\mathrm{M}$ & $\mathrm{M}$ \\
\hline $\mathrm{L}$ & $\mathrm{L}$ & $\mathrm{L}$ & $\mathrm{L}$ & $\mathrm{L}$ & $\mathrm{L}$ & $\mathrm{L}$ & $\mathrm{L}$ & $\mathrm{L}$ & $\mathrm{L}$ & $\mathrm{L}$ & $\mathrm{L}$ \\
\hline$X$ & $\mathrm{X}$ & $X$ & 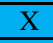 & $\bar{X}$ & $\bar{X}$ & $\mathrm{X}$ & $\mathrm{X}$ & $\mathrm{X}$ & $\mathrm{X}$ & $\bar{X}$ & $\mathrm{X}$ \\
\hline $\mathrm{T}$ & $\mathrm{T}$ & $\mathrm{T}$ & $\mathrm{T}$ & $\mathrm{T}$ & $\mathrm{T}$ & $\mathrm{T}$ & $\mathrm{T}$ & $T$ & $\mathrm{~T}$ & $\mathrm{~T}$ & $\mathrm{~T}$ \\
\hline $\mathrm{G}$ & $\bar{G}$ & $\mathrm{G}$ & $\mathrm{G}$ & $\mathrm{G}$ & $\mathrm{G}$ & $\mathrm{G}$ & $\mathrm{G}$ & $\mathrm{G}$ & $\bar{G}$ & $\mathrm{G}$ & $\mathrm{G}$ \\
\hline $\mathrm{W}$ & $\mathrm{W}$ & $\mathrm{W}$ & $\mathrm{W}$ & $\mathrm{W}$ & $\mathrm{W}$ & $\mathrm{W}$ & $\mathrm{W}$ & $\mathrm{W}$ & $\mathrm{W}$ & $\mathrm{W}$ & $\mathrm{W}$ \\
\hline $\mathrm{Z}$ & $\mathrm{Z}$ & $\mathrm{Z}$ & $\mathrm{Z}$ & $\mathrm{Z}$ & $\mathrm{Z}$ & $\mathrm{Z}$ & $\mathrm{Z}$ & $\mathrm{Z}$ & $\mathrm{Z}$ & $\mathrm{Z}$ & $\mathrm{Z}$ \\
\hline D1 & D1 & D1 & D1 & D1 & D1 & D1 & D1 & D1 & D1 & D1 & D1 \\
\hline $\mathrm{C} 1$ & $\mathrm{C} 1$ & $\mathrm{C} 1$ & $\mathrm{C} 1$ & $\mathrm{C} 1$ & $\mathrm{C} 1$ & $\mathrm{C} 1$ & $\mathrm{C} 1$ & $\mathrm{C} 1$ & $\mathrm{C} 1$ & $\mathrm{C} 1$ & $\mathrm{C} 1$ \\
\hline $\mathrm{A} 1$ & $\overline{\mathrm{A} 1}$ & A1 & A1 & $\mathrm{A} 1$ & $\mathrm{~A} 1$ & A1 & A1 & A1 & A1 & A1 & A1 \\
\hline B1 & B1 & B1 & B1 & $\overline{\mathrm{B} 1}$ & B1 & B1 & B1 & B1 & B1 & B1 & B1 \\
\hline G1 & G1 & G1 & G1 & $\mathrm{G} 1$ & G1 & G1 & G1 & G1 & G1 & G1 & G1 \\
\hline E1 & E1 & E1 & E1 & E1 & E1 & E1 & E1 & E1 & E1 & E1 & E1 \\
\hline F1 & F1 & $\mathrm{F} 1$ & F1 & $\mathrm{F} 1$ & F1 & F1 & F1 & F1 & F1 & F1 & F1 \\
\hline $\mathrm{Y}$ & $\mathrm{Y}$ & $\mathrm{Y}$ & $\mathrm{Y}$ & $\mathrm{Y}$ & $\mathrm{Y}$ & $\mathrm{Y}$ & $\mathrm{Y}$ & $\mathrm{Y}$ & $\mathrm{Y}$ & $\mathrm{Y}$ & $\mathrm{Y}$ \\
\hline
\end{tabular}

${ }^{1}$ Učitelům byla poskytnuta charakteristika těchto pojmů. 


\begin{tabular}{|c|c|c|c|c|c|c|c|c|c|c|c|}
\hline U1 & U2 & U3 & U4 & U5 & U6 & U7 & U8 & U9 & U10 & U11 & U12 \\
\hline CH1 & CH1 & CH1 & CH1 & CH1 & CH1 & CH1 & CH1 & CH1 & CH1 & CH1 & CH1 \\
\hline H1 & H1 & H1 & H1 & H1 & H1 & H1 & H1 & H1 & H1 & H1 & H1 \\
\hline J1 & J1 & J1 & J1 & J1 & J1 & J1 & J1 & J1 & J1 & J1 & J1 \\
\hline I1 & I1 & I1 & I1 & I1 & I1 & I1 & I1 & I1 & I1 & I1 & I1 \\
\hline K1 & K1 & K1 & K1 & K1 & K1 & K1 & K1 & K1 & K1 & K1 & K1 \\
\hline L1 & L1 & L1 & L1 & L1 & L1 & L1 & L1 & L1 & L1 & L1 & L1 \\
\hline M1 & M1 & M1 & M1 & M1 & M1 & M1 & M1 & M1 & M1 & M1 & M1 \\
\hline
\end{tabular}

Tabulka č. 7: Členěni kompetenci na kličcové, základni a prahové (posouzeni experty).

Získané výsledky i přes částečnou různorodost umožňují rozčlenění modelu do tř́ oblastí. V př́ipadě odlišení klíčových a základních kompetencí je možné vést linii mezi kompetencemi označenými $H$ a R. V prŕpadě hranice mezi základními a prahovými kompetencemi vedeme linii mezi kompetencemi označenými jako D1 a C1. Po překódování kompetencí do textové podoby a následném grafickém zpracování dospíváme $\mathrm{k}$ dále prezentovanému zobrazení kompetenčního třístupňového modelu.

\subsubsection{Oblast klíčových kompetencí}

Názory expertů směřovaly $\mathrm{k} z$ zahrnutí deseti kompetencí s nejvýznamnějším hodnocením důležitosti mezi klíčové. Můžeme si povšimnout, že jsou specifické pro oblast badatelsky orientované výuky. Jejich uplatnitelnost v jiných, blízkých situacích je možná, nicméně není předpokládána.

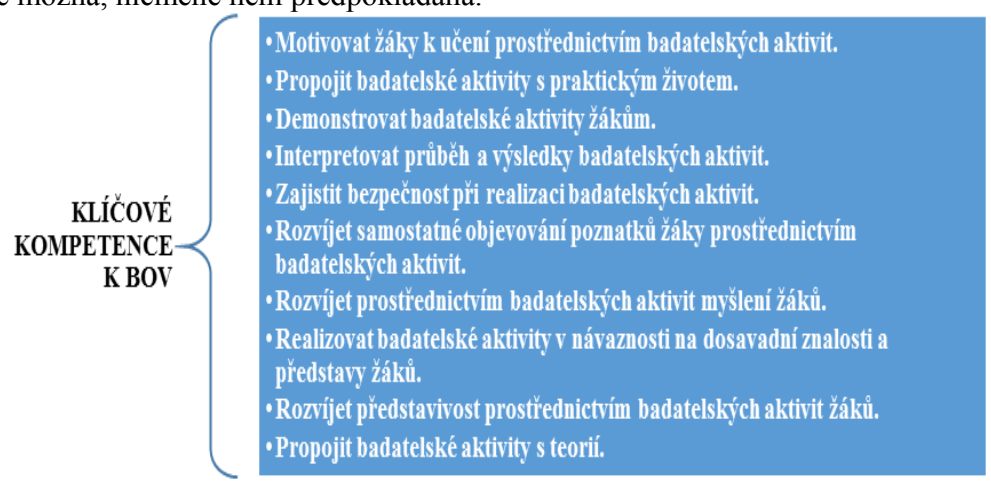

Obrázek č. 1: Klíčové kompetence učitele technických a přirodovédných předmètů $k$ badatelsky orientované výuce

\subsubsection{Oblast základních kompetencí}

Dalších v pořadí 16 kompetencí lze na základě názorů expertů považovat za základní. Opět souvisí velmi úzce s badatelsky orientovanou výukou, avšak mají již větší potenciál přenositelnosti i do akceptačně pojaté výuky. 


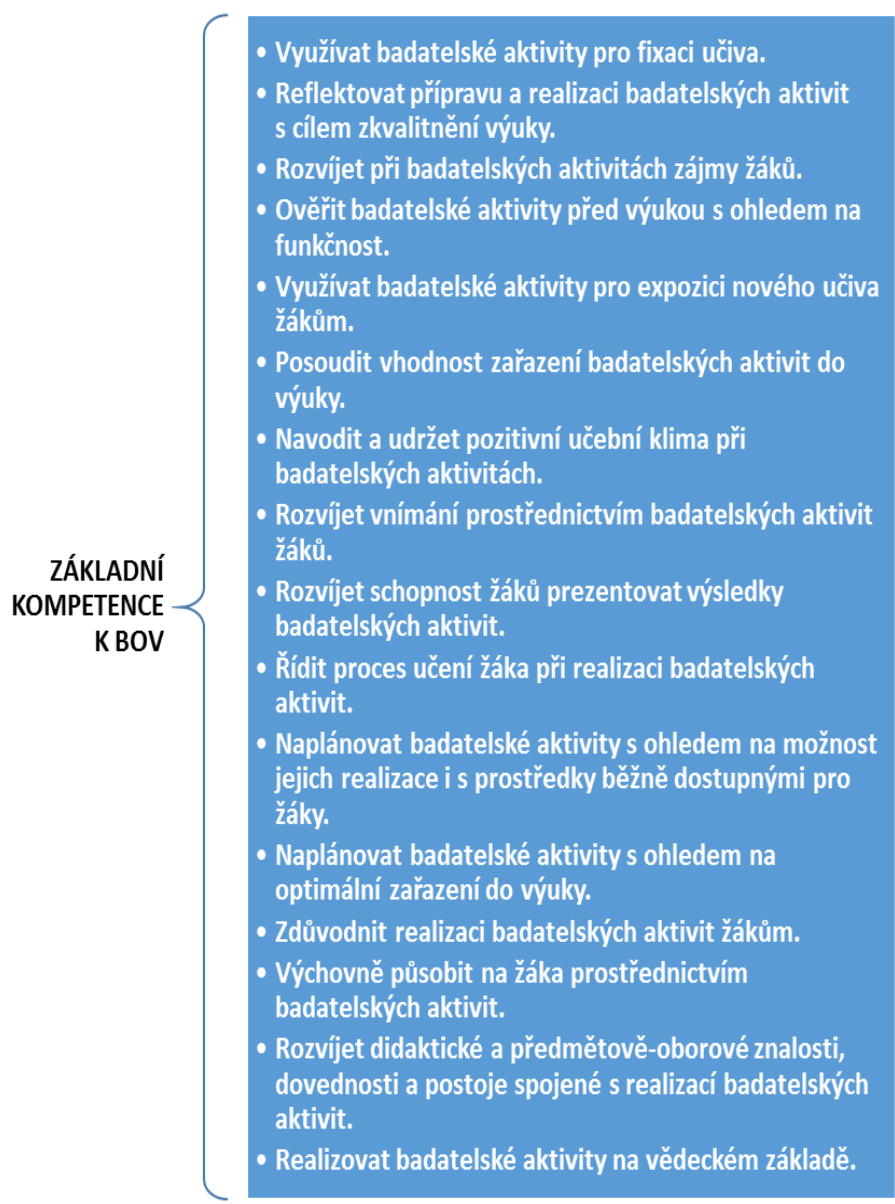

Obrázek č. 2: Základní kompetence učitele technických a př́rodovédných předmětů $k$ badatelsky orientované výuce

\subsubsection{Oblast prahových kompetencí}

Třetí oblast kompetenčního modelu zahrnuje 14 prahových kompetencí. Pokud učitel patřičnými kompetencemi nedisponuje, ocitá se již za hranicí kompetentnosti. I přesto se může jednat o učitele s vynikajícími výchovně vzdělávacími výsledky, avšak př̀i snaze provádět badatelsky orientovanou výuku je možné předpokládat selhání. 


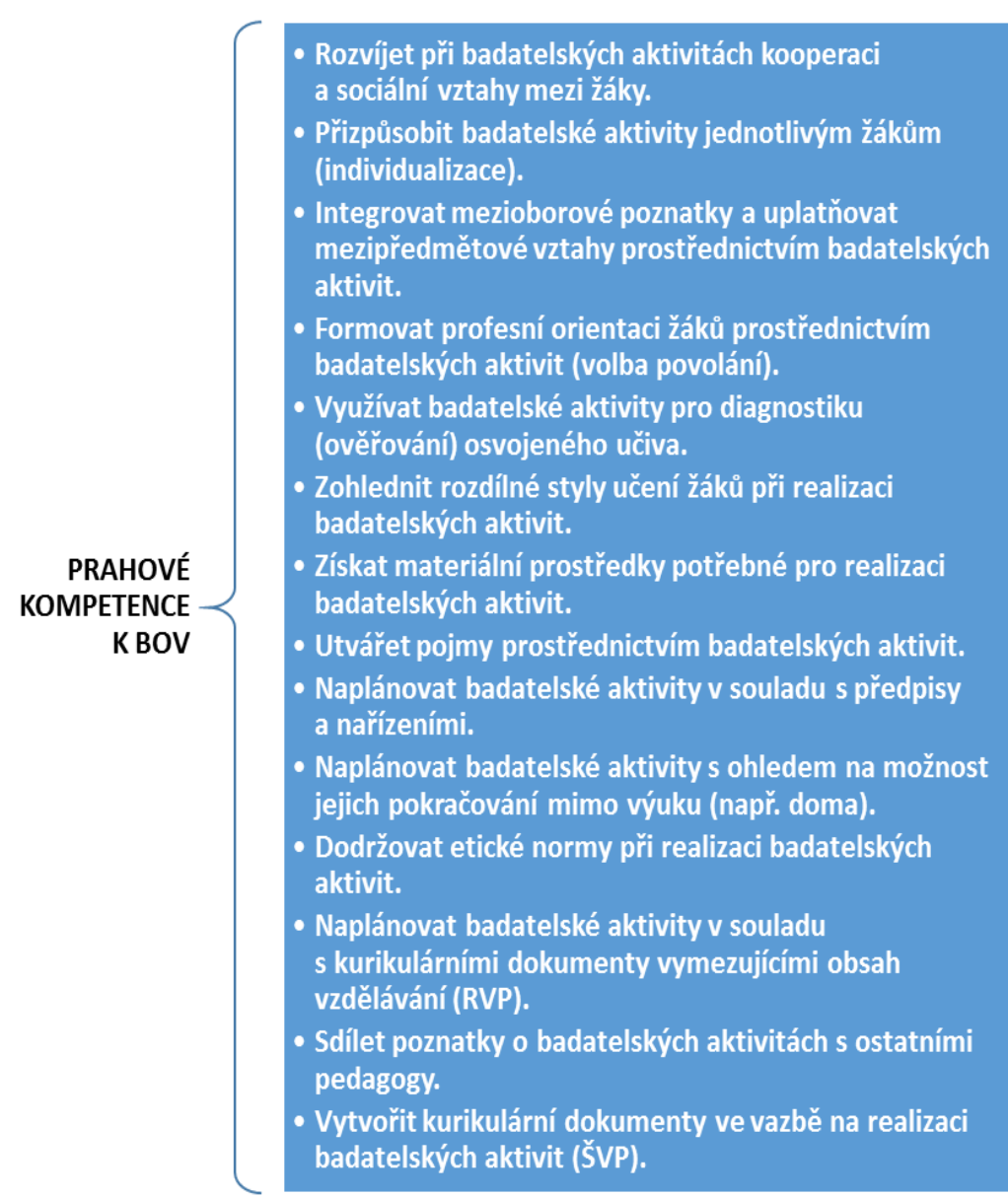

Obrázek č. 3: Prahové kompetence učitele technických a př́rodovédných předmètů $k$ badatelsky orientované výuce

\section{Diskuse výsledků}

Nejdřive se zaměříme na zasazení dosažených výsledků, vázaných na príistupy učitelů $\mathrm{k}$ realizaci badatelsky orientované výuky $\mathrm{v}$ rámci jimi vyučovaných předmětů, do kontextu s výsledky vybraných empirických výzkumných šetření. Ukazuje se, že zjištění, ke kterým dospěli např. P. A. Kirschner, J. Sweller a R. A. Clark (2006) a A. Colburn (2000) v souvislosti s požadavkem na patřičnou kompetenční výbavu učitelů, jsou platná i v našich podmínkách. Taktéž v rámci České republiky je možné považovat souvislost adekvátních kompetencí učitelů $\mathrm{s}$ výslednou podobou badatelsky orientované výuky za zřetelnou. Rovněž jsme se střetli s jevem, na který upozornili C. J. Eick a B. Stewart (2010) a C. T. Forbes a E. A. Davis (2010), 
a to že postojová rovina sehrává významnou roli nejen v př́ípadě projektování výuky, ale i v její výsledné podobě.

Provedeme-li $\quad \mathrm{v}$ souvislosti $\mathrm{s}$ vytvořeným kompetenčním modelem učitele technických a prrírodovědných předmětů „návrat do teorie“, můžeme si povšimnout, že mezi nejvýznamnějšími kompetencemi obsaženými v modelu se nachází pouze tř́ z deseti, které byly navrženy na základě teoretických analýz. Návrh všech ostatních z uvedených deseti nejvýznamnějš́ích kompetencí vychází z praxe, ale i uvedené tři kompetence byly praxí reflektovány. Jakoby se mj. projevoval pomyslný př́kop (bariéra) mezi pedagogickou teorií a praxí, jehož odhalení je však př́nosné pro další práce, které mohou napomoci jejich většímu sepětí (srov. Maňák, 2011, s. 260).

Za významný aspekt považujeme provázanost (resp. koherenci) vytvořeného kompetenčního modelu s již existujícími představami promítajícími se do dokumentů na úrovni Evropské komise. Z provedené analýzy zahraničních řídicích dokumentů i výsledků různých výzkumných šetření (mj. Paaso a Korento, 2010) vyplynulo, že dosavadní dílčí snahy o vytvoření kompetenčního modelu nebyly plně kompatibilní s podmínkami v Evropské unii. Tomuto požadavku jsme se snažili vyhovět zohledněním již existujícího rámce (srov. European Commission, 2013).

$\mathrm{Na}$ základě dosažených výsledků i poznatků ze zahraničí (např. Australian Institute for Teaching and School Leadership, 2011; Commission on Teacher Credentialing, 2009) dospíváme $\mathrm{k}$ závěru, že badatelsky orientovaná výuka a její provádění by neměla mít odraz pouze $\mathrm{v}$ kurikulárních dokumentech, ale $\mathrm{i}$ dokumentech usměrňujících (standardizujících) činnost učitele.

\section{Závěr}

Řešená problematika představovala málo probádanou oblast bez existence ucelenější teoretické báze. Proto se práce nejdříve orientovala na analýzu aktuálního stavu poznání, a to nejen u nás, ale i v zahraničí, jelikož se jevila jako př́nosná poznatková transmise ze zahraničí do našich podmínek. Na základě komparativních analýz a induktivních, ale v mnoha prínadech i deduktivních úvah došlo k pojmovému vymezení a teoretickému zakotvení řešené problematiky.

Empirická část spočívala $\mathrm{v}$ návrhu kompetenčního modelu učitele technických a prírodovědných předmětů $\mathrm{v}$ kontextu badatelsky orientované výuky. Její podoba je typická pro smíšený design výzkumu, čemuž odpovídá metodologické prolínání a v neposlední řadě i vracení se do teorie.

Pro splnění cíle projektu bylo žádoucí výzkumně zjistit, jak moc a které kompetence učitelů technických a př́rodovědných předmětů jsou důležité pro realizaci badatelsky orientované výuky na základních školách a dále, které individuální předpoklady učitelů jsou považovány za významné součásti vymezených kompetencí důležitých pro realizaci badatelsky orientované výuky. Cíle bylo dosahováno řešením tří výzkumných problémů. Jako stěžejní explorativní metoda byla zvolena Q-metodologie, která umožňovala intenzivní zkoumání, a přesto bylo možné naměřené údaje podrobit statistickému zpracování a dosáhnout při tom reliabilních výsledků.

Řešením vymezených problémů se podařilo přispět $\mathrm{k}$ obohacení teorie pedagogiky, respektive její disciplíny didaktiky, pojímané jako teorie vzdělávání. Poznatky obecného charakteru jsou aplikovatelné $\mathrm{i} v$ jednotlivých předmětových a oborových didaktikách, kde se mohou promítnout na úrovni plánování výuky, na úrovni cílů, metodické, organizační, i na úrovni materiálního zajištění výuky. Mohou být užity jako již „hotové“, 
anebo se mohou stát podkladem pro pokračující oborově specifická výzkumná šetření. Poznatky zaměřené na technické a př́rodovědné vzdělávání jsou uplatnitelné $\mathrm{v}$ didaktikách těchto předmětů a pozitivně tak mohou přispět $\mathrm{k}$ jejich rozvoji.

Výsledky mohou nacházet uplatnění i v pedagogické disciplíně orientované na učitele, v pedeutologii, a to zejména část zaměřená na učitelské kompetence. I přsesto, že je pedagogická teorie v oblasti kompetencí dle našeho názoru na kvalitní úrovni, ukazuje se, že jsou v malé míře rozpracovány aspekty přesahující do roviny didaktické. Tento nedostatek se částečně podařilo překlenout zaměřením práce na oblast učitele technických a prrírodovědných předmětů. Bylo by ale vhodné pokračovat v práci i v rámci jiných předmětů.

Významným, můžeme uvést, že i nejpodstatnějším přínosem práce je návrh, konstrukce a ověření kompetenčního modelu učitele technických a prírodovědných předmětů ve vztahu $\mathrm{k}$ provádění badatelsky orientované výuky. Výsledek této vědeckovýzkumné činnosti je př́nosný nejen v rovině rozvoje teorie, ale i pro pedagogickou praxi, a to na několika úrovních. První je př́íprava budoucích učitelů v rámci pregraduálního stupně studia, ale vedle toho $\mathrm{i}$ v rámci celoživotního vzdělávání. V souladu $\mathrm{s}$ trendy projevujícími se $\mathrm{v}$ technickém a přírodovědném vzdělávání je možné cíleně rozvíjet kompetence budoucích učitelů, které aktuálně vyžaduje pedagogická praxe. Druhou úrovní je vzdělávání na základních školách, kde se kompetenční model může stát součástí evaluačních procesů s cílem nalezení oblastí možného rozvoje učitelů a zkvalitnění vzdělávání jako celku s pozitivním dopadem na žáka.

V souvislosti s řešením problémů, které byly předmětem této práce, vyplynula celá řada skutečností hodných pozornosti a dalších otázek s potenciálem rozvoje pedagogické teorie i praxe. Některé $\mathrm{z}$ nich, zejména ty méně závažné, jsou již na našem pracovišti řešeny na úrovni bakalářských a diplomových prací. Alespoň na některé ze závažnějších se budeme snažit upozornit $\mathrm{v}$ následujícím textu.

Jako první je možné uvést oblast didaktických situací, v rámci kterých probíhá bádání žáků. $Z$ pozorování vyplynulo, že tyto situace jsou specifické, mající vniťrní zákonitosti a řád a podléhající vlivům $\mathrm{z}$ vnějšku. Didaktické situace považujeme za stěžejní faktor ovlivňující míru úspěšnosti rozvoje žáka, avšak současně i za značně neprobádané, mj. postupy jejich navozování, jejich dynamika, postupy efektivního řízení atp.

Druhá z možností pokračování práce je zaměřní na moderní vzdělávací technologie, které stále častěji nabízí prvky umožňující aplikaci badatelských aktivit do výuky. Je na místě zmínit nevázanost badatelsky orientované výuky na prostředí, ve kterém probíhá. Může se jednat o běžnou školní tř́ídu, specializovanou školní laboratoř, ale v poslední době stále častěji elektronická vzdělávací prostředí, $\mathrm{v}$ některých př́ípadech i s prvky virtuální reality. Elektronická podpora výuky tedy není k badatelsky orientované výuce protikladem, ani nejsou v rozporu. Je na škodu, že se poměrně často vyskytují elektronické prostředky nepodporující badatelské aktivity žákủ, tj. takové, které je nepobízejí k aktivnímu myšlení, kladení otázek a hledání odpovědí, k vlastní činnosti s učivem, a to i manipulativního charakteru, pokud to situace sohledem na rozvoj kompetencí vyžaduje. Učení z nich bývá navíc často pro žáka emotivně poměrně chudé. Velké naděje jsou nově vkládány do vzdálených laboratoří (remote laboratory) nebo remotely controlled laboratory) a virtuálních laboratoří (virtual laboratory).

Třetí možností pokračování práce je transfer poznatků do didaktik jiných, nežli technických a prrírodovědných předmětů a následné výzkumné práce za účelem 
modifikace námi navrženého a zkonstruovaného kompetenčního modelu. Stejně tak jako je podoba výuky $\mathrm{v}$ jiných předmětech odlišná, mohou být odlišné i kompetence učitelů $\mathrm{k}$ navozování, ř́zení a hodnocení badatelských aktivit žáků. V další rovině může pokračovat výzkum ne na úrovni jiných předmětů, ale v rámci neformálního vzdělávání, které je rovněž pro rozvoj jedince podstatné.

\section{Literatura}

Abels, S. (2014). Inquiry-Based Science Education and Special Needs - Teachers' Reflections on an Inclusive Setting. Journal of Education. roč. 2, č. 2, s. $124-154$. Allake-Tuenter, E., H., Biemans J. A., Tobi, H., Wals, A. E. J., Oosterheert, I. \& Mullder, M. (2012). Inquiry-Based Science Education Competencies of Primary School Teachers: A literature study and critical review of the American National Science Education Standards. International Journal of Science Education. roč. 34, č. 17, s. 2609 -2640 .

Australian institute for teaching and school leadership. (2011). National Professional Standards for Teachers [online]. [cit. 2014-08-04]. Dostupné z: http://www.aitsl.edu.au/docs/default-source/default-document-library/aitsl_national_ professional_standards_for_teachers

Avraamidou, L. \& Zembal-Saul, C. (2010). In search of well-started beginning science teachers: Insights from two first-year elementary teachers. Journal of Research in Science Teaching. roč. 47, č. 6, s. $661-686$.

Bader, R. \& Müller, M. (2002). Leitziel der Berufsbildu Handlungskompetenz. Die berufsbildende Schule. roč. 54, č. 6, s. $176-182$.

Belz, H. \& Siegrist, M. (2001). Klíčové kompetence a jejich rozvíjení: východiska, metody, cvičení a hry. Praha: Portál.

Calderhead, J. (1989). Reflective teaching and teacher education. Teaching and Teacher Education. roč. 5, č. 1, s. $43-51$.

Colburn, A. (2000). An Inquiry Primer. Science Scope. Special issue. roč. 23, č. 6, s. 42 44.

Commission on Teacher credentialing. (2009). California Standards for the Teaching Profession (CSTP) [online]. [cit. 2014-08-04]. Dostupné z: http://www.ctc.ca.gov/educator-prep/standards/CSTP-2009.pdf

Cruickshank, D. R. \& Haefele, D. (2001). Good Teachers, Plural. Educational Leadership. roč. 58 , č. 5 , s. $26-30$.

Day, Ch. (2012). Efektivní učitelé a jejich vášnivé zaujetí kvalitou. Orbis scholae. roč. 6, č. 3 , s. $9-26$.

Dostál, J. (2015). Badatelsky orientovaná výuka: Pojetí, podstata, význam a prínosy. Olomouc. UP.

Duncan, R. G., Pilitsis, V. \& Piegaro, M. (2010). Development of Preservice Teachers' Ability to Critique and Adapt Inquiry-based Instructional Materials. Journal of Science Teacher Education. roč. 21, č. 1, s. 1 - 14.

Důvody nezájmu žáků o prírodovédné a technické obory [online]. 2008. Výzkumná zpráva. MŠMT, [cit. 2014-07-31]. Dostupné z: http://ipn.msmt.cz/data /uploads/portal/Duvody_nezajmu_zaku_o_PTO.pdf.

Eick, Ch. J. \& Stewart, B. (2010). Dispositions Supporting Elementary Interns in the Teaching of Reform-Based Science Materials. Journal of Science Teacher Education. roč. 21 , č. 7 , s. $783-800$. ISSN 1046-560X. 
European Commision. (2013). Supporting teacher competence development for better learning outcomes. $\quad 59 \quad \mathrm{~s}$ Dostupné na: http://ec.europa.eu/education/policy/school/doc/teachercomp_en.pdf.

Fazio, X., Melville, W., Bartley, A. \& Jones, D. (2008). Experience and Reflection: Preservice Science Teachers' Capacity for Teaching Inquiry. Journal of Science Teacher Education. roč. 19 , č. 5 , s. $477-494$.

Forbes, C. T. \& Davis, E.A. (2010). Curriculum design for inquiry: Preservice elementary teachers' mobilization and adaptation of science curriculum materials. Journal of Research in Science Teaching. vol. 47, č. 7, s. 820 - 839.

Glen, N. J. \& Dotger, S. (2009). Elementary teachers' use of language to label and interpret science concepts. Journal of Elementary Science Education. roč. 21. č. 4, s. 71 83.

Glynn, S. M. \& Winter, L.K. (2004). Contextual Teaching and Learning of science in elementary schools. Journal of Elementary Science Education. roč. 16, č. 2. s. 51 - 63.

Gonzales Thompson, A. (1984). The relationship of teachers' conceptions of mathematics and mathematics teaching to instructional practice. Educational Studies in Mathematics. roč. 15 , č. 2 , s. $105-127$.

Grimmet, P. P. \& Erickson, G.L. (1988). Reflection in teacher education. New York: Teacher College Press.

Grossman, P. L. (1990). The making of a teacher: teacher knowledge and teacher education. New York: Teachers College Press, Teachers College, Columbia University. Hustler, D. \& McIntyre, D.G. (1996). Developing competent teachers. London: David Fulton Publishers.

Chambers, C. (2002). Multi-Curricular Inquiry-Based Learning. City College of the City University of New York: condor.admin.ccny.cuny.edu/.../ carlchambers.researchpaper.doc

Chráska, M. (2007). Metody pedagogického výzkumu: základy kvantitativního výzkumu. Praha: Grada Publishing.

Improving Teacher Quality in the United States: Paper 3 [online]. [cit. 2014-10-05]. Harvard Graduate School of Education. Dostupné z: http://isites.harvard.edu/fs/ docs/icb.topic1203150.files/Panel\%203\%20\%20Activating\%20the\%20Greatest\%20Pow er/Lin_Li_50865444_US_TeacherQuality_submitted.pdf

Inquiry and the National Science Education Standards: a guide for teaching and learning. (2000). Washington, D.C.: National Academy Press, xviii.

Janík, T., Maňák, J., Knecht, P. \& Němec, J., (2010). Proměny kurikula současné české školy: vize a realita. Orbis scholae. roč. 4, č. 3, s. 9 - 35 .

Jung, E. (2005). Aspekte des Kompetenzerwerbs, Unterricht - Arbeit +Technik, roč. 32, č. 8, s. 53-55.

Katz, L., Sadler, K. \& Craig, D.V. (2005). Science professors serve as mentors for early childhood preservice teachers in the design and implementation of standards-based science units. Journal of Elementary Science Education. roč. 17, č. 2, s. 43-55.

Kim, M. \& Tan, A. (2011). Rethinking difficulties of teaching inquiry-based practical work: stories from elementary pre-service teachers. International Journal of Science Education. roč. 33, s. $465-486$.

Kirschner, P. A., Sweller, J. \& Clark, R. E. (2006). Why Minimal Guidance During Instruction Does Not Work: An Analysis of the Failure of Constructivist, Discovery, 
Problem-Based, Experiential, and Inquiry-Based Teaching. Educational Psychologist. roč. 41 , č. 2 , s. $75-86$.

Kleve, B. (2007). A study of teachers' views on the teaching and learning of mathematics, their intentions and their instructional practice. In: Relating Practice and Research in Mathematics Education. Proceedings of NORMA 05, Fourth Nordic Conference on Mathematics Education. Editor Christer Bergsten, Barbro Greveholm, Heidi S. Måsøval, Frode Rønning. Trondheim: Tapir Academic Press, s. 361 - 373.

Klieme, E., Maag-Merki, K. \& Hartig, J. (2010). Kompetence a jejich význam ve vzdělávání. Pedagogická orientace, roč. 20, č. 1, 104-119.

Korthagen, F. A. J. (2004). In search of the essence of good teacher: toward a more holistic approach in teacher education. Teaching and Teacher Education. roč. 20, č. 1, s. $77-97$.

Lazarová, B. (Ed.). (2006). Cesty dalšího vzdělávání učitelů. Brno: Paido.

Lee, O., Hart J.E., Cuevas, P. a Enders, C. (2004). Professional development in inquirybased science for elementary teachers of diverse student groups. Journal of Research in Science Teaching. roč. 41, č. 10. s. $1021-1043$.

Leonard, J., Boakes, N \& Moore, C.M., (2009). Conducting science inquiry in primary classrooms: Case studies of two preservice teachers' inquiry-based practices. Journal of Elementary Science Education. roč. 21, č. 1, s. $27-50$.

Maaß, K. \& Euler, M. PRIMAS WP9 - Report about the survey on inquiry-based learning and teaching in the European partner countries, 2011. EU-Project PRIMAS, Deliverable $\mathrm{N}^{\circ} 9.2$.

Magnusson, S., Kajcik, J. \& Borko, H. (2002). Nature, Sources, and Development of Pedagogical Content Knowledge for Science Teaching. In: Examining Pedagogical Content Knowledge. Dordrecht: Kluwer Academic Publishers.

Marble, S. (2007). Inquiring into Teaching: Lesson Study in Elementary Science Methods. Journal of Science Teacher Education. roč. 18. č. 6. s. 935 - 953.

Martinello, M. L., (1998). Learning to Question for Inquiry. Educational Forum. roč. 62, č. 2 , s. $164-171$.

McDonald, S. \& Butler Songer, N. (2008). Enacting classroom inquiry: Theorizing teachers' conceptions of science teaching. Science Education. roč. 92. č. 6. s. 973 - 993.

Nezvalová, D. (2007). Pedagogické kompetence. In: Kompetence a standardy $v$ počátečni prípravě učitelů prírodovédných předmětů a matematiky. Editor Martin Bílek. Olomouc: UP, s. $7-20$.

Organisation for Economic Co-operation and Development. (2006). Evolution of Student Interest in Science and Technology Studies: Policy Report [online]. [cit. 2014-08-03]. Dostupné z: http://www.oecd. org/science/sci-tech/36645825.pdf

Paaso, A. \& Korento, K.. (2010). The Competent Teacher 2010-2020: The competences of teaching staff in upper secondary vocational education and training [online]. [cit. 2014-10-11]. Dostupné z: http://www. oph.fi/download/122136_The_competent_teacher_2010-2020.pdf

Palmer, P. J., (1998). The Courage to Teach: Exploring the landscape of a teachers' life. San Francisco: Jossey-Bass.

Pelikán, J. (2004). Základy empirického výzkumu pedagogických jevů. Praha: Karolinum. Píšová, M. (2010). Učitel-expert: přehled výzkumných trendů a jejich výsledků. Pedagogika. roč. 60, č. 3-4, s. $242-253$. 
Pollard, A. \& Tann, S. (1987). Reflective Teaching in the Primary school. London: Cassel.

Prawat, R.S. (1977). Problematizing Dewey's Views on Problem Solving: A Reply to Hiebert et al. Educational Researcher. roč. 26, č. 2, s. $19-21$.

Průcha, J. (2002). Moderní pedagogika. Praha: Portál.

Průcha, J. (2009). Přehled pedagogiky. Praha: Portál.

Rikmanis, I., Logins, J. a Namsone, D. (2012). Teacher Views on Inquiry-based Science Education. In: 1ST INTERNATIONAL PROFILES CONFERENCE, 24th - 26th September 2012 a C BOLTE. Inquiry-based science education in Europe: reflections from the PROFILES project : book of invited presenters. Berlin: Freie Universität, s. 14 16. ISBN 9783000394034.

Science Education in Europe: National Practices, Policies and Research, 2011. Brussels: European Commission.

Sikko, A. S., Lyngved, R. \& Pepin, B. (2012). Working with Mathematics and Science teachers on inquiry-based learning (IBL) approaches: Teacher beliefs. Acta Didactica Norge. r. 6, č. 1, čl. 17.

Spilková, V. \& Wildová, R., (2014). Potřebujeme kvalitní nebo kvalifikované učitele? Pedagogická orientace. roč. 24, č. 3, s. 423-432.

Spilková, V. (2010). Evropské př́stupy k pojetí kvality učitele - optikou formálních dokumentů. Pedagogika. roč. 60 , č. 3-4, s. $70-80$.

Steinberg, R.J. \& Hotvath, J.A., (1995). A prototype view of expert teaching. Educational Researcher. roč. 24, č. 6, s. 9 - 17.

Špok, D. (2014). Povolání, zaméstnání, pracovní pozice nebo profese? Dostupné na: http://www.etlabora.cz/povolani-zamestnani-pracovni-pozice-profese/

Švaříček, R. (2006). Životní historie učitele experta. In Současné metodologické př́stupy a strategie pedagogického výzkumu. Sborník príspěvkü 14. konference ČAPV (CDROM). Plzeň: Západočeská univerzita v Plzni, s. 1-17.

Švec, Vlastimil, (1999). Pedagogická př́prava budoucích učitelů: problémy a inspirace. Brno: Paido.

Talis 2013 Results: An International Perspective on Teaching and Learning, 2014. OECD.

Tobon, S. (2009). Formación Basada en Competencias [online]. [cit. 2012-12-29]. Dostupné z: http://www.slideshare.net/ MAESTRIACID/formacion-basada-encompetencias-pdf

Tomková, A. (2005). Rozvoj klíčových kompetencí a pojetí výuky. Kritické listy. č. 20, s. 5 - 8 .

Vališová, A., Kasíková, H. (2007). Pedagogika pro učitele. Praha: Grada.

Van Zee, E., H., Hammer, D., Bell, M., Roy, P. \& Peter, J. (2005). Learning and teaching science as inquiry: A case study of elementary school teachers' investigations of light. Science Education. roč. 89., č. 6, s. 1007-1042.

Vašutová, J. (2007). Být učitelem: co by měl učitel vědèt o své profesi. Praha: Univerzita Karlova v Praze.

Vermeersch, J. (2005). Začněme s ODL. Apeldoorn: Garant.

Walterová, E. (2002). Proměny školního kurikula, jeho tvorba a projektování. In: Konferencia o školskom kurikule: Budmerice 18.-19. novembra 2002. Editor Ludovít Hrdina. Bratislava: Metodicko-pedagogické centrum, s. 5 - 21. 
Weinert, F. E., (2001). Concept of Competence: a Conceptual Clarification. In: Defining and Selecting Key Competencies. Editor Dominique Rychen, Laura Salganic. Göttingen: $\mathrm{H}$ and $\mathrm{H}$ Publishers, s. $45-65$.

Weld, J. \& Funk, L., (2005). "I'm Not the Science Type": Effect of an Inquiry Biology Content Course on Preservice Elementary Teachers' Intentions About Teaching Science. Journal of Science Teacher Education. roč. 16, č. 3, s. 189 - 204. 